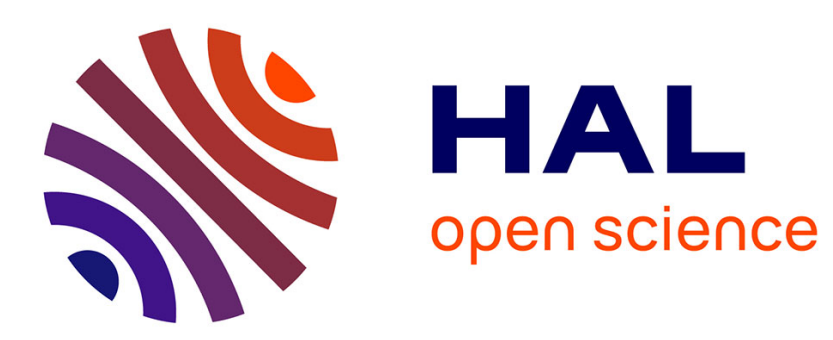

\title{
Transport corridors and regional balance in China: the case of coal trade and logistics
}

Chengjin Wang, César Ducruet

\section{To cite this version:}

Chengjin Wang, César Ducruet. Transport corridors and regional balance in China: the case of coal trade and logistics. Journal of Transport Geography, 2014, 40, pp.3-16. halshs-01069149

\section{HAL Id: halshs-01069149 \\ https://shs.hal.science/halshs-01069149}

Submitted on 28 Sep 2014

HAL is a multi-disciplinary open access archive for the deposit and dissemination of scientific research documents, whether they are published or not. The documents may come from teaching and research institutions in France or abroad, or from public or private research centers.
L'archive ouverte pluridisciplinaire HAL, est destinée au dépôt et à la diffusion de documents scientifiques de niveau recherche, publiés ou non, émanant des établissements d'enseignement et de recherche français ou étrangers, des laboratoires publics ou privés. 


\title{
Transport corridors and regional balance in China: the case of
}

\section{coal trade and logistics}

\author{
Dr. Chengjin WANG \\ Key Laboratory of Regional Sustainable Development Modeling \\ Institute of Geographical Sciences and Natural Resources Research \\ Chinese Academy of Sciences, Beijing 100101, China \\ Email: cjwang@igsnrr.ac.cn \\ Dr. César DUCRUET ${ }^{1}$ \\ National Centre for Scientific Research (CNRS) \\ UMR 8504 Géographie-cités \\ F-75006 Paris, France \\ Email:cdu@parisgeo.cnrs.fr
}

\begin{abstract}
Pre-final version of the paper published in Journal of Transport Geography, special issue on "The Changing Landscapes of Transport and Logistics in China", Vol. 40, pp. 3-16.
\end{abstract}

\begin{abstract}
Coal plays a vital role in the socio-economic development of China. Yet, the spatial mismatch between production centers (inland Northwest) and consumption centers (coastal region) within China fostered the emergence of dedicated coal transport corridors with limited alternatives. Serious problems of energy shortage and power rationing have already affected southeastern China. At the same time, enormous interregional coal transfers face a lack of transport capacity along the transport system. Based on first-hand statistics, a disaggregated analysis of coal distribution patterns since the late 1970s provides novel evidences about the local effects of macroscopic trends, such as the shift from dominant exports to dominant imports in terms of changing traffic concentration levels and distribution patterns among routes and ports. The spatial evolution of coal distribution is also discussed in terms of related industry linkages and local influences, coal trade policies and market pricing, port system evolution, and transport network planning. The paper also discusses possible improvements of the current situation through enhancing multimodal transport based on a review of current policies.
\end{abstract}

Keywords: bulk; China; coal; multimodal transport; port system; spatial dislocation; transport network

\footnotetext{
${ }^{1}$ Author for correspondence
} 


\section{Introduction}

Since the mid-1840s, coal has been playing a significant role in global socio-economic development (Vaninetti et al., 1995). The Chinese economy is largely dependent on coal (Kuby et al., 2011; Todd, 1997; Sun et al., 2005), which accounts for more than $66.6 \%$ of its total energy consumption (Browne, 2000; Richard et al., 2007) as opposed to $18.8 \%$ for oil, $9.4 \%$ for hydroelectricity, and 5.2\% for natural gas in 2012. Since 1978, China has witnessed substantial economic growth and it has become nowadays the world's largest energy consumer (Shen, 2012), handling about a quarter of global coal trade in 2013. While it is currently the world's largest coal producer, its coal consumption reached 3.61 billion tons of standard coal in 2012, 6.16 times the amount in 1980. Domestic coal production has long remained its main resource, in addition to limited imports, but the latter has gradually occupied an unprecedented importance. Important effects of such changes are felt globally in terms of trade routes reorientation and energy security (Ekawan \& Duchene, 2006; Lin et al., 2010; Ma, 2008; Ritschel, 2009) as well as locally. Notably, coastal provinces are confronted with coal insufficiency (Shealy et al., 2010) due to rising transport and mining costs (Paulus et al., 2011) that lead to regular shortages and power rationing. New questions thus emerge about China's ability to tackle those challenges. In such context, the mismatch between the spatial distribution of coal mining, transformation, transfer activities and the pattern of transport infrastructure (i.e., ports and railways) and other socio-economic activities is seen in this paper as one major constraint when responding to the aforementioned issues. How can transport and logistics alleviate this situation, and what are the relevant planning solutions?

Such questions are not new in general academic literature, and specifically within a Chinese context. Earlier studies by renowned experts have provided a clear understanding of the major trends affecting China's changing energy structure and policy (Sinton et al., 1998; Smil, 1998). A brief overview, however, is needed to identify more specific issues in relation to coal trade and logistics. Coal-related literature traditionally focuses on transport costs and modal split as well as their optimization (Chang et al., 1980; Kania, 1984) in different contexts (Elmes, 1984), such as North America (Ash et al., 1991; Kuby et al., 1991; Leblancetal et al., 1978). Studies conducted in China analyzed the exploitation potential of coal reserves and its relation with domestic demand (Tang, 2008; Ma et al., 2009), the relationship between coal consumption and Gross Domestic Product (GDP) (Raymond et al., 2012), the forecast of such linkages (Chan et al., 1997; Crompton et al., 2005; Shiu et al., 
2004; Yuan et al., 2008; Lin et al., 2010), and coal policies (Shen et al., 2001; Shen \& Gao, 2012). Spatial dynamics have also been studied, such as the westward shift of coal production due to higher costs of deeper extraction in East China (Dorian, 2005; Tao et al., 2007), the interregional transfer of coal resources since the 1970s (Cheng et al., 2008; Wang, 2009), and the construction of the coal transport network and spatial pattern of coal traffics (Fan, 1997; Liu, 1999; Zhang, 2002). Some scholars have particularly stressed the emergence of transport bottlenecks (Wang et al., 2009) and the widening gap between supply and demand of coal (Todd and Zhang, 1994a, 1994b; Todd, 1997; Todd and Jin, 1997), notably from a historical perspective, while others have adopted more sophisticated methods, such as Geographical Information Systems (GIS), to examine China's future railway developments (Kuby et al., 2001).

Yet, the existing research remains much dispersed across the disciplinary spectrum. The changing spatial linkages between distribution, production, and consumption have only been partly addressed. A synthetic analysis taking into account transport, logistics, trade, industrial, and policy issues is thus the target of this paper. The discussion in this paper will cover the time from 1980s to now, paying special attention to the time since the early 1990s.

\section{Main trends of coal production, distribution, and trade in China}

\subsection{Production and consumption of coal resources}

According to the statistics of BP, China possessed approximately 114.5 billion tons of proved coal reserves in 2012, and China's Statistics Bureau stated that 229.9 billion tons are basic resources in 2012. Yet, coal reserves are concentrated in North and Northwest China, north of the Kunlun, Qinling, and Dabie mountains. The area north of this belt accounts for $93.1 \%$ of the national total, with a decreasing gradient from west to east and from north to south (Ma et al., 2009). Disparities can also be measured at the province level. Shanxi and Inner Mongolia account for $39.5 \%$ and $17.5 \%$ of reserves, respectively. Other provinces of Xinjiang, Shaanxi, and Henan concentrate 15.7\% altogether while Shandong, Guizhou, Heilongjiang, Yunnan, and Sichuan provinces account for $14.1 \%$. Although the region of West Guizhou, South Sichuan, and East Yunnan possess about $9 \%$ of total reserves, they represent the largest coal base in South China. 
The exploitation and production of coal resources is influenced in its spatial pattern by factors other than production volumes. As shown in Figure 1, total coal output has increased to such an extent that it now dominates China's energy structure, accounting for $66.6 \%$ of total China's energy consumption in 2012, with a temporary decline between 1996 and 2001. The Asian financial crisis provoked a production drop for many companies, resulting in the reduction of coal consumption and production. Coal mining occurs in 1100 of the 2100 counties possessing this resource, but it is highly concentrated in few locations. Concentration has increased over time, as demonstrated by Todd (1997) when calculating a coefficient of localization by province. In 2007, Shanxi achieved about $25 \%$ of China's total raw coal production, maintaining its rank as the largest production center. Yet, Shanxi dropped to the second rank (21.96\%) in 2012 after Inner Mongolia (25.05\%). Together with Shaanxi and Henan, the four provinces constitute the leading coal base and exporting region with about $62.1 \%$ of China's total in 2012.

[Insert Figure 1 about here]

Coal consumption is concentrated in North China and the Bohai Rim, with Shandong accounting for more than $9.2 \%$ of China's total in 2012. Shanxi, Hebei, Henan, Inner Mongolia, and Jiangsu concentrate one-third. Shanxi, Inner Mongolia, and Shandong are important for consumption, production, and export. China's coal consumption was forecasted to reach 4.8 billion tons in 2020 and to grow by 1.2 billion tons in the subsequent eight years, according to the Annual Report on Coal Industry in China (2013) edited by the China National Coal Association. According to the report on China's Energy and Long-term Development Strategy (2030-2050), coal consumption may reach 5.1-6.4 billion tons in 2030 and increase to 5.9-7.8 billion tons in 2050 (Chinese Academy of Engineering, 2011).

In addition to those trends, some major changes in China's industrial structure over the contemporary period are important factors that need to be considered. The two first five-year plans from the 1950s to the early 1960s focused on the development of heavy and chemical industries, which shared total economic activity and grew rapidly but long remained inferior to the share of other sectors. In more recent decades, notably after 1998, China's economic development relied mostly on energy-intensive industries (i.e., thermal power, metallurgy, and construction), which fostered the consumption of domestic and also foreign coal. In 2012, 
China owned the world's largest coal-fired power generation with $819 \mathrm{GW}$. Coal consumption grew at an annual rate of 9.8\% over the period 1998-2012 (Shen, 2012) while thermal power output grew from 512.8 billion kilowatt-hours in 1997 to 3787 billion kilowatt-hours in 2012. It is likely that such trend will be prolonged in light of the $7.2 \%$ GDP annual growth rate forecasted by the 12th Five-Year Plan.

Most of the imported coal is steaming coal for thermal power plants, followed by coking coal for steelworks, fueling the expansion of heavy industries in this region (Table 1). For example, many thermal power plants located in this region benefit from maritime shipping. As shown in Table 2, the installed capacity and output of thermal power plant in this region accounts for about $48.7 \%$ and $50.4 \%$ of China's output in 2011. Particularly, Jiangsu, Shandong, Guangdong, and Zhejiang become the core, and their above indicators amount to $30.2 \%$ and $31.4 \%$, respectively. The thermal power plants in the YRD consume mainly domestic coal and import a small quantity of the foreign coal while the plants at the south of the Yangtze River depend largely on the import coal. The thermal power plants in this region consumed about $70 \%$ of import coal in 2012. The thermal coal of Shandong, Jiangsu, Guangdong, and Hebei exceeded 100 million tons in 2011, and Zhejiang, Liaoning, and Fujian reached over $5 \times 107$ tons. Importantly, all coastal provinces have a high share of thermal power coal in their total coal consumption. The share of Hainan exceeds $70 \%$, those of Guangdong and Zhejiang exceed 60\%, and Shanghai, Fujian, Jiangsu and Tianjin reach over $50 \%$. The rapid growth of electricity demand since 2000 led by increased industrial and residential use led to power shortages in many provinces of China. The increasing import of coal, to some extent, accommodated the growing shortfalls of the aforementioned regions.

[Insert Table 1 about here]

[Insert Table 2 about here]

Among the coal bases, most provinces constructed a great amount of mine-mouth power, as shown in Table 3. Shandong, Inner Mongolia, Shanxi, and Henan generated most thermal power, over 240 billion $\mathrm{kWh}$, followed by Anhui, Shaanxi, and Guizhou, surpassing 100 billion kW.h. Between 2006 and 2012, thermal power generation has increased greatly, specifically in areas such as in Anhui (145\%), Ningxia (154.4\%), Inner Mongolia (116.8\%), and Shaanxi (115.3\%). Correspondingly, this stimulated the growth of thermal power coal 
consumption. In 2012, Inner Mongolia, Shandong, Henan, and Shanxi consumed over 100 million tons of thermal power coal, respectively. In view of the electricity transmission, Shandong has the highest transmission, with a rate of over $75 \%$, while Ningxia also achieved a rate of 53.8\%, followed by Anhui, Heilongjiang, and Henan. Particularly, Henan increased its transmission rapidly, from $41.5 \%$ in 2006 to $71.8 \%$ in 2012 .

[Insert Table 3 about here]

\subsection{Spatial mismatch of the coal supply-demand}

China's economy and population are characterized by a profound imbalance between coastal and inland regions, which has important effects on coal distribution (Todd, 1997). Since its opening in the late 1970s, China's economic development took place mostly in the coastal region, resulting in rapid urbanization and industrialization around main cities and their adjacent economic zones from Liaoning to Guangxi, as this area comprised $57.9 \%$ of the GDP, $65.1 \%$ of the industrial value, and $44.9 \%$ of the population in 2012 . Especially, Bohai rim (22.9\%), Yangtze River Delta (18.9\%), Pearl River Delta (9.9\%), and Southeast Fujian became known as China's main economic clusters in which the demand increased from $45.9 \%$ to $49.1 \%$ of China's total energy between 1990 and 2012 (see Table 4). While the coastal region concentrates $56.7 \%$ of total power consumption, the six provinces of Guangdong, Jiangsu, Shandong, Zhejiang, Hebei, and Liaoning account for $44.3 \%$. As the most developed regions, they possess large-scale thermal power plants, building materials, steel industry, chemicals industry, and manufacturing, which require enormous coal volumes.

[Insert Table 4 about here]

Despite their plentiful coal reserves, Northwest Chinese provinces remain far less developed, with $10.5 \%$ and $7.7 \%$ of China's GDP and industrial output in 2012. The coastal region that concentrates most export-oriented industries has only $7.7 \%$ of total China's total coal reserves, and a coal output was limited to $9.96 \%$ in 2012. Furthermore, complex mining conditions fostered high mining costs while poor coal quality resulted in limited utilization value. Despite such constraints, some provinces, such as Liaoning and Shandong have been engaged in local coal mining, until the drying up of their reserves. Coastal provinces are thus exposed to large shortages to meet their coal demand, which reflects their poor capacity of energy 
supply and influences profoundly their sustainable development (Todd et al., 1994b).

As a whole, the coal consumption of the major energy-intensive industries currently represents 2.84 billion tons and assumes $84.5 \%$ of the total industrial coal in 2012, including $51.9 \%$ for the electric power industry, $7.39 \%$ for the ferrous metals industry, $10.86 \%$ for the petroleum processing industry, $5.3 \%$ for the chemical materials manufacture, and $9.02 \%$ for the manufacture of non-metallic mineral products. Thermal power is China's primary coal user with $51.9 \%$ of its total concentrated mostly in Shandong, Jiangsu, Guangdong, Hebei, and Zhejiang. The ratio between thermal coal and total coal consumption provides an interesting differentiation among Chinese provinces (Table 1), among which some reach over 60\% (Shanghai, Jiangsu, Zhejiang, Hainan, Guangdong), 40\% (Tianjin, Inner Mongolia, Anhui, Jiangxi, Guangxi, Fujian, Gansu, and Ningxia, Xinjiang), and the remaining provinces reaching 20\%. Thermal power dominated China's energy structure with $80 \%$ in 2009 . It is not likely that such an imbalanced structure will change drastically in the near future, even though Chinese authorities plan to grow nuclear power and renewable energies, aiming to reduce the share of thermal power to $72 \%$ (Lin et al., 2009).

Overall, while this spatial mismatch creates the internal reliance of consumption regions on production regions based on railway and coastal transfers ( $\mathrm{Li} \& \mathrm{Lu}, 1995$; Tang \& La Croix, 1993), Chinese authorities have chosen to import coal mostly from overseas. For provinces, such as Guangdong, Guangxi, Fujian, and Hainan, which are located away from the major coal production bases, it is more profitable to import coal from countries such as Vietnam, Indonesia, and Australia. Such decisions are exacerbated by energy shortages felt at numerous Chinese regions.

\subsection{Coal shortage}

Since the 1980s, rapid industrization and urbanization produced a giant coal demand. Many provinces nowadays are confronted with energy shortage and rely increasingly on coal imports. As shown in Figure 2, the distribution of coal shortage has changed over time, but is clearly affecting primarily coastal provinces in the recent period. The number of provinces affected by coal shortage has increased from 17 in 1986 to 19 in 1991 and 26 in 2000. While in 1986, the shortage in such provinces was lower than 30 million tons, this volume increased rapidly to 100 million tons for Jiangsu, Hebei, and Shandong in 2005, and recently also for 
Guangdong, Zhejiang, Liaoning, and Hubei. Such evolutions depict a serious energy crisis, affecting the coastal region and as such, the entire country.

[Insert Figure 2 about here]

Interestingly, several provinces with a large coal output also suffer from coal shortage. Such a phenomenon already started in the mid-1980s, as seen in the case of Liaoning (44.8 million tons of coal production vs. 26.3 million tons of coal shortage in 1986), Hunan, Shandong, Hebei, Sichuan, and Jiangxi where the shortage sometimes surpasses the output. Figure 2 well illustrates the concentration of coal-deficit provinces in the coastal area and of coal-surplus provinces in the Northwest. Some provinces are more balanced, such as in Central China (Shanxi, Inner Mongolia, and Anhui), as Shanxi for instance became the largest coalexporting region in the 1990s already. In the West, however, coal shortage is felt in several provinces (Tibet, Sichuan, Chongqing, Gansu) compared with others being excedentary (Shaanxi, Guizhou, Xinjiang, Qinghai, Ningxia, and Yunnan). In 2012, Jiangsu, Shandong, Hebei, Guangdong, Hubei, Zhejiang, and Liaoning experienced the highest shortage, accounting for over two-thirds of the entire shortage. The most economically productive provinces all face such problems, with the top ten provinces accounting for $75.9 \%$ of the total shortage and the least 10 productive provinces having 99.5 million tons of coal surplus in 2012. Although such problems are not new in China, since in the 1970 s, more than $20 \%$ of China's industrial capacity was idle because of coal shortage (Todd et al., 1994b), this issue becomes paramount. It creates industrial production bottlenecks and fosters social instability, notably across coastal provinces, with frequent power cuts and even blackouts in many cities nowadays, when coal shortage is coupled with inclement weather conditions ${ }^{2}$. Such vulnerability of energy supply in China directly influences and explains coal trade dynamics in China (Todd \& Zhang, 1994b), as discussed in the next section.

\subsection{Coal trade evolution}

In China, the self-production of coal has long been the major approach to support domestic

\footnotetext{
${ }^{2}$ The recent case is the snowstorm in South China in 2008. From December 2009 to January 2010, the snowstorm swept North China and resulted in the shortage crisis of the coal stockpiles. It compelled several provinces to ration electricity for industrial use, including Shanghai, Jiangsu, Hubei, Zhejiang, Guangxi and Anhui. In Anhui, its 15 main thermal power plants, accounting for $75 \%$ of its total power plants, had coal stockpiles less than the warning mark of 7 days.
} 
consumption while imported coal was only a complementary resource. The evolution of coal exports and imports has been influenced by multiple factors, including the aforementioned spatial mismatch between coal supply and demand, the soaring growth of coal demand, changes in coal trade policies, the integration of the coal industry, and the gap between domestic and overseas coal prices (Sagawa \& Koizumi, 2007).

Over the past decade, the amount of imported coal has increased rapidly and even explosively in recent years (Figure 3). Despite some fluctuations of imports and exports, over the 19802012 period, the years 2002-2003 mark a turning point in the evolution. In 2003 and 2008, imported coal reached 10.8 million and 40.8 million tons respectively, accounting for onesixth of global coal trade in 2010. By 2011, imports dominated and China overtook Japan to become the largest importer. Conversely, the amount of exported coal fell sharply. Coal has long been an important component of China's mineral export, precisely since 1949 when it began to export it on the scale of 1.5 million tons. Coal exports had been increasing rather slowly since the early 1980s, experiencing a rapid growth after the 1998 Asian financial crisis, with 2003 representing the highest peak historically. However, it has been experiencing a decline from 45.4 million tons in 2008 to 7.5 million tons in 2013.

[Insert Figure 3 about here]

China reached the status as the world's third largest coal exporter in 2003. Previously, China has long been a net exporter, with exports exceeding the imports. The share of imported coal has also been rising continuously, but is still lower than that of exported coal. Therefore, China is still a net coal exporter. In 2007 and 2008, nearly equal amounts of coal were exported and imported, reaching an equilibrium state. It also marks the start of a transition stage from a net exporter to a net importer. The reversal occurred after 2009, with a widening gap in subsequent years, revealing that China's socio-economic development begins to rely on foreign coal in unprecedented ways. Its vulnerability to international market fluctuations becomes significant, implying greater risks and substantially lower energy security.

As shown in Figure 4, most imported coal is concentrated at southern coastal provinces, such as Guangdong, Shanghai, Guangxi, Zhejiang, and Jiangsu. Despite important fluctuations in the shares among provinces, we can observe that major exporting areas have also been increasingly importing (i.e., Liaoning, Hebei, Tianjin, and Shandong) since 2002-2003. 
Among large importers are large urban regions, such as Guangdong, Shanghai, and Zhejiang, while Jiangsu, Hainan, Guangxi, and Fujian have recently seen their imports soaring. Overall, in the 1970s, coal imports were concentrated in East and South China, the latter holding the share of $80-90 \%$. Subsequently, South China's share gradually decreased to around $60 \%$ in the 1980s, to the advantage of Bohai and Fujian regions. Notably, the Bohai region increased its share from $15.3 \%$ in 2005 to $23.5 \%$ in 2012 . Regardless of the period, South China has always been the main coal-importing region.

\section{[Insert Figure 4 about here]}

Externally, and for a long time, China has been exporting coal mainly to adjacent countries and regions (Table 5). Asia accounted for $89 \%$ of its exports in 2005, followed by Europe (5.7\%) and the Americas (4.4\%). Regarding different countries, Japan imports about $30.8 \%$ of China's exported coal while South Korea and Taiwan import 25.3\% and 19.3\%, respectively, followed by India, Belgium, Philippines, Brazil, and Turkey. Despite their decrease in volume, coal exports' distribution pattern remained unchanged by 2010. Coal imports from overseas reached farther distances on average. While Vietnam, Indonesia, and Australia are main exporters to China, the ranking of countries changed substantially across the years. In 2005, Asia as a whole exported $68.6 \%$ of total Chinese imported coal, followed by Oceania (23.1\%), the Americas (4.7\%), and the former Soviet Union (3.6\%) and lastly North Korea, Indonesia, and Mongolia, accounting for 10\%. China's coal-importing sources tend to diversify over time, as the United States, South Africa, Colombia, and Canada joined the list of top exporters in recent years.

[Insert Table 5 about here]

Of interest is also the foreland distribution of coal trade by Chinese province. For instance, Guangdong imports coal mainly from the ASEAN (55.8\%), followed by Australia (26.5\%) and Russia (14.5\%), and a similar profile applies to Jiangsu, Shanghai, and Zhejiang. Indonesia accounts for important shares in Guangxi (21.8\%) and Fujian (83\%). Regarding the effect of proximity, Shandong's biggest partner is North Korea (32\%), just like Hebei and Liaoning provinces are for anthracite. 


\section{Coal transport and logistics in China}

\subsection{Modal split of coal transfers}

Spatial mismatch between production and consumption created the need to transfer coal over long distances through a transit network. Coal is transported predominantly by railway (60\%), water (30\%), and road (10\%). North-south coal traffic accounts for $75 \%$ of the total, including $53.5 \%$ of southward coal and $21.5 \%$ of northward coal. The east-west coal traffic accounts for $25 \%$ of the total of which $21 \%$ is eastward coal and $4 \%$ is westward coal. Therefore, it shapes a spatial pattern of coal transfer from west to east and from north to south. Figure 5 summarizes the current trend by which rail flows increase rapidly and water flows remain rather quick.

[Insert Figure 5 about here]

Since the 1980s, other dedicated lines, such as Daqin (Datong-Qinhuangdao), ShenHuang (Shenfu-Huanghua), Xinshi line (Xinxiang-Rizhao), HanJi (Handan-Jinan), Houyue (HoumaYueshan), and Hanchang (Handan-Changzhi), complemented Chinese railway network. Coal traffic now assumes more than half of total rail freight, reaching 1.8 billion tons in 2012, while the average travelled distances have continuously increased since the 1990s (Table 6).

[Insert Table 6 about here]

An examination of coal flows by rail in 2009 provides a clear picture of the overall spatial logic (Figure 6). Main traffics concentrate in East and Central China (i.e., North China, Central Plains), far beyond West and Southeast China. The coal-railway network is organized mainly around major coal bases, such as Shanxi and Henan, for shifting coal eastward and southward, thereby forming actual corridors, including several major lines ${ }^{3}$ among which Jingbao and Hukun lines are fully dedicated and carry the heaviest traffic. Daqin line alone carries up to 426 million tons of coal, and in 2012, it accounted for $24 \%$ of total traffics. From north to south, several other lines are dominant ${ }^{4}(\mathrm{Wu}, 2008)$, whereas coal is also transported by other lines carrying also other commodities. Overall, railways connecting ports belong to

\footnotetext{
${ }^{3}$ Daqin, Shenhuang, Longhai, Xinyue (Yueshan-Xinxiang), Xinshi, Jiaoji (Jinan-Qingdao), Shitai (ShijiazhuangTaiyuan), Shide (Shijiazhuang-Taiyuan), Jingbao (Beijing-Baotou) and Hukun (Shanghai-Kunming) lines.

4 Jinghu, Jingguang, Ningxi (Nanjing-Xi'an), Jiaoliu (Jiaozuo-Liuzhou), Lizhan (Litang-Zhanjiang), and Huainan (Huainan-Wuhu) lines.
} 
major corridors ${ }^{5}$, and most of those lines are dedicated entirely (Daqin), dominantly (Jinghu, Jingguang about 57\%), or significantly (over 30\%) to coal traffics. Dedicated lines connect primarily the Dantong coalfield (Daqin, Shenhuang, Fengshada, Jitong) but also the Taiyuan (Shitai line) and the Changzi (Taiyuan-Jiaozuo, Houyue, Hanchang, and Longhai lines) coalmines.

After the 1990s, China strengthened the rail-water combined network for coal transfers (Todd, 1997), reaching 154 million tons and accounting for $19.6 \%$ of total coal traffic in 1995 . The rapid growth of North China ports boosted this same traffic to 799.6 million tons in 2012 . Major coal loading ports are located at the northern coastal region (e.g., Qinhuangdao, Tianjin, Huanghua, Jingtang, Qingdao, Rizhao, and Lianyungang) and along the Yangtze River Valley (YRV) (Table 7). In total, those ports comprise 61 specialized coal-loading berths and 561 million tons of coal-loading capacity. Northern seaports contain the majority of such equipment, with a capacity of 450 million tons, and traffic of 510 million tons accounting for $82.1 \%$ of total coal shipping. Coal river ports are concentrated in the YRV (e.g., Nanjing, Wuhan, Wuhu, Zhicheng, Chongqing, Wanzhou, Huainan, Luzhou, and Yibin), and few of them are found along the Grand Canal (Xuzhou) and the Pearl River Valley (Guigang), representing a total coal traffic of 128 million tons in 2009. Northern seaports supply mainly Shanghai, Jiangsu, Zhejiang, Fujian, and Guangdong. Unloading ports are concentrated at the mouth of Yangtze River and Pearl River (i.e., Shanghai, Ningbo, Zhenjiang, Nantong, Suzhou, Zhoushan, Taizhou, Wenzhou, Fuzhou, Zhangzhou, Xiamen, Shantou, Shenzhen, Guangzhou, Zhuhai, Jiangmen, Beihai, Qinzhou, and Haikou). In 2005, these ports owned 80 specialized coal berths and 260 million tons of unloading capacity, but unloaded only 330 million tons, being confronted with serious capacity shortage. Although in 2009 such figures have reached 161 coal berths, a coal-unloading capacity of 500 million tons, and a traffic of 669 million tons, they still face capacity insufficiency.

\section{[Insert Table 7 about here]}

As mentioned earlier, capacity shortage of railway prompted the development of road transfers in recent years. Road transport plays an increasing role in the coal-export of the TWR and Yunnan-Guizhou bases. For instance, road transport assumed about 30\% of

\footnotetext{
${ }^{5}$ Daqin, Shenhuang, Longhai, Jiaoji, Jingguang, Huainan, Jiaozhi, Xinshi, and Jinghan lines.
} 
Shanxi's coal exports (360 million tons) in 2004. Thirteen major highways connect the TWR base (e.g., Datong-Yuncheng and Taiyuan-Jiuquan expressways) as well as national highways (no. 109, 108, 307, 309, and 207) and provincial highways (Datong-Zhangjiakou, YuciXingtai, Changzhi-Anyang, Jincheng-Jiaozuo, Zuoquan-Handan, and Gaoping-Hebi). Coal is transferred from Shanxi to its adjacent regions: Hebei, Beijing, Tianjin, Shandong, Henan, and North Anhui. Certain ports lack rail connections for coal transport, such as Tianjin, where road occupies $40 \%$ of its total coal traffic.

[Insert Figure 6 about here]

\subsection{Coal traffics in the Chinese port system}

Since the mid-1980s, the spatial distribution of coal exports (Figure 7) has been characterized by certain stability, with a dominance of Northern ports (Stone, 1995). In the 1980s, China began to export coal to its neighbors mostly through Northern ports, with Qinhuangdao concentrating about $75 \%$ of total port traffics, followed by Lianyungang (15\%). The number of coal-exporting ports increased from 11 to 16 in 1995 due to a diffusion of this specialization. Qinhuangdao's traffic, connected by the heavy-load Daqin line completed in 1992 to Shanxi base, accounted for $45.5 \%$ of total coal port traffics in 1995, followed by Tianjin (29.2\%), Rizhao (12.7\%), and Lianyungang (10.1\%). The subsequent explosive growth of coal port traffics resulted in a continuous increase of the number of ports handling coal (24 in 2005) and a decreased share of Qinhuangdao (40.9\%) and Tianjin (23.4\%). On the other hand, other ports such as Huanghua, the terminal of Shenhuang railway completed by 2002 (Goldstein, 1992), reached a share of $12.8 \%$ in 2005. Although the rapid decrease in coal exports that followed did not modify profoundly the spatial pattern, ports such as Tianjin, Huanghua, and Qinhuangdao were struck hard, and the number of coal-exporting ports fell to about 19 ports.

[Insert Figure 7 about here]

The spatial distribution of coal imports, interestingly, offers a very contrasting picture and evolution. In the mid-1980s, only a small number of ports imported rather small volumes of coal, Shanghai being the largest one and accounting for $58.3 \%$ of total imports in 1986 . This situation remained stable until the mid-1990s, when Guangzhou concentrated $45.8 \%$ of total 
imports, followed by Ningbo (25.4\%) and Shanghai (20.4\%). This pattern changed rapidly since then mainly due to a sharp increase in total volumes. In 2002, Guangzhou remained the largest coal-importing port, but its share dropped to $25.7 \%$ of total imports, followed by a majority of southern ports (e.g., Taiping, Putian, Zhanjiang, Ningbo, and Shanghai), altogether comprising $86.9 \%$ of total imports. Rizhao is one rare example at the time of growing imports among Northern ports. By 2004, the number of coal-importing ports reached 41 and their traffic has been more widespread across the entire country, since northern ports (e.g., Bohai) began to import coal. This trend continues to today, as volumes keep increasing, with about 58 coal-importing ports in 2012. Fangcheng near the Vietnam border is the largest importer, followed by Guangzhou in the south and Jingtang in the north. While Guangzhou supplies mainly coal to the Pearl River Delta, it also transfers it to the hinterland (Hunan, Jiangxi) via the Beijing-Guangzhou and Hangzhou-Zhuzhou railway lines. Similarly, Fangcheng both supplies local power plants and transfers coal through water transshipment (Hainan, Guangdong) and rail-water transport (Guangxi-Hunan and Nanning-Fangcheng lines). Port traffic growth in the south is thus backed by important investments in new port facilities as well as double-track railways, as also seen in Fujian with Xiamen, Fuzhou, Quanzhou, and Xiaocuo. River shipping serves as a crucial inland transport mode, notably along the Yangtze from Shanghai and Zhangjiagang towards the distant hinterland (e.g., Anhui, Hubei, and Jiangxi). Such drastic spatial dynamics shall be analyzed also from the perspective of inland shipping. The question is how the landward distribution network has been able to accommodate such changes.

\section{[Insert Figure 8 about here]}

China's enormous demand for coal resources necessitates a long-term strategy, which is reflected in the development of coal bases. The national coal policy launched in 2007 by the government in 2007 has three aims:

- Accelerate coal reserve prospection and build large coal bases in the central region to stabilize the raw coal output and enhance the self-sufficiency of the coastal region.

- Build 13 large coal bases covering 98 coalfields and more than 500 coal mines to increase the total output of raw coal from 1.83 billion tons in 2005 to 5.1 billion tons in 2027, among which the largest bases (i.e., Shandong, North Shanxi, Central Shanxi, East Shanxi, Huanglong, and North Shaanxi) shall assume $90 \%$ of all coal export (Ma et al., 2008); 
- Build an efficient distribution network between main production and consumption areas in order to limit coal transfers across the country based on geographic proximity, except from Huanglong and East Ningxia, which would also supply eastern areas.

\subsection{Coal transport corridors}

Since road transport could not absorb coal traffics for technical reasons (Todd, 1997), railways and rail-water intermodal systems are of chief concern to undertake such flows (Wang, 2009). Yet, the rapid increase of coal transport by rail has in many cases outpaced the capacity of the network. This is also because trunk lines, such as Jinghu, Jingguang, Longhai, and Hukun, combine both general goods, passengers, and coal. The existing railway thus needed urgent expansion to link the large coal bases to the major coal-deficit regions and loading ports. Deploying dedicated corridors and/or lines has been a solution to avoid congestion and shorten the distance between coalfields and the coast. In addition, electrification greatly favored the upgrading of existing railways (Todd, 1997) and gave more capacity to the coal transfer.

\subsubsection{Railway corridors}

As seen in Table 8, the spatial pattern of coal-producing regions consists of four main coal transport corridors. The northern corridor consists of Daqin, Fengda, Shenhuang (double track, electrified), and Jingyuan (single track, not electrified) lines connecting North Shanxi and Shenfu coal bases. Daqin and Shenhuang lines are dedicated railways and connect Datong and Shenfu coalfields directly to assume the bulk of coal supply directed towards the coastal region. However, this corridor confronts serious capacity deficiency of coal transfer; hence, the two existing routes need to be updated and a third dedicated line needs to be built from Zhungeer to Caofeidian port to export out the coal of West Inner Mongolia, North Shaanxi, and East Ningxia, and to heighten its capacity to 800 million tons. Shitai, Taizhong, Hanji, Shide, Jiaoji (double track, electrified), and Hanchang (single track, electrified) lines form the second corridor to shift the coal from Central Shanxi, Central Hebei and East Shanxi. Due to the deficit in railway capacity, the plentiful coal of West Shanxi could not be exported and a new route from Luliang to Rizhao port should be added to form a new rail-coal corridor (Figure 9). Taijiao (north part of this line, single track, not electrified; south part of this line, double track, electrified), Houyue, Longhai (double track, electrified), and Ningxi (single 
track, electrified) lines shape the fourth corridor that connects Southeast Shanxi and Shaanxi coal bases. There is an urgent need to construct the second route of Ningxi and a dedicated passenger line from Xuzhou to Lanzhou to devote Longhai line to freight. These corridors would possess the capacity of 1.58 billion tons of coal-transfer in total.

[Insert Table 8 about here]

[Insert Figure 9 about here]

A southward corridor is also being developed via the Jingguang, Jiaoliu, and Jingjiu (BeijingShenzhen) lines (double track and electrified) between the Henan coal base and Wuhan, Changsha-Zhuzhou-Xiangtan, and the Pearl River Delta. This corridor also transships coal from the east-west railways, such as Shitai, Longhai, Shenhuang, and Xinshi (single track, electrified) lines. In particular, the Jiaoliu line has benefitted from increased electrification, as a dedicated passenger line was constructed to avoid the mix with freight. The capacity of this corridor should reach 130 million tons of coal after all projects are completed. One recent and major development is the construction of one mega coal corridor from the coal bases of Haolebaojie in West Inner Mongolia to Jiean in Jiangxi province, which calls at Yulin, and Yan'an in Shaanxi, Yuncheng in Shanxi, Sanmenxia, and Nanyang in Henan province, Xiangyang and Jingzhou in Hubei, and Yueyang in Hunan province. Construction started in October 2012 and operations are planned to start in 2017. When completed, this new coal corridor will be $1860 \mathrm{~km}$ long and provide a capacity of 250 million tons, thereby supplying Hubei, Hunan, and Jiangxi provinces. In terms of investment shares, the Chinese Ministry of Transport occupies $20 \%$ while the other $80 \%$ come from eleven energy groups or coal enterprises and local governments.

An East China corridor emerged based on the vicinity of West Shandong and HuainanHuaibei coal bases to the coastal region, thus necessitating a connection with Rizhao port via the eastward Xinshi line, with Wuhu port via the Huainan line, and with the Yangtze River Delta via the Jinghu (double track, electrified) line. This corridor should enhance its coal capacity to 320 million tons by upgrading Huainan and Xinshi lines and freeing the freight capacity of Jinghu line after the construction of the Jinghu passenger-dedicated railway. Finally, the South China corridor consists of Nankun (single track, electrified), Zhuliu (Zhuzhou-Liu'an, double track, electrified), and Qingui (Guizhou-Liuzhou, single track, not 
electrified) lines and connects the coal base of Yunnan-Guizhou with South China. Due to serious overloading, existing railways are being upgraded through electrification and construction of a secondary line. Moreover, one passenger-dedicated line from Kunming to Guangzhou should be built to devote Nankun line to freight. These constructions can form a large-capacity corridor from Yunnan-Guizhou base to the Pearl River Delta and increase the capacity to 200 million tons of coal transportation.

\subsubsection{Rail-water intermodal corridors}

Since the mid-1990s, a rail-water intermodal system has gradually complemented the sole rail system. An estimation provided by Todd (1997) revealed that $70 \%$ of coal traffic was transported by railways alone while rail-sea and rail-river were utilized only $25 \%$ and $5 \%$ respectively. Coal is thus transferred from west to east and then from north to south by being first collected from the coalfields, transported by rail to northern seaport, and transshipped to the unloading port and the final user (e.g., thermal power plant) in the southeast coastal region. Another possibility is to ship coal to East China over the Yangtze River or the Grand Canal after collecting it from Henan, Anhui, and Shandong provinces by rail. According to the respective spatial distributions of coal bases, railway, and waterway networks, four rail-water intermodal corridors are being constructed. The coastal and canal corridors organize mainly coal transfer from west to east and from north to south while the Yangtze and the Xi river corridors handle coal haulage from west to east.

The coastal corridor first transfers coal from northwest production bases to northern loading seaports by rail and then to southern unloading ports by coastal shipping (i.e., Jiangsu, Shanghai, Zhejiang, Fujian, and Guangdong). It ensures about $60 \%$ of southeast thermal coal consumption. Main railway lines include Daqin (Datong-Qinhuangdao) and Shenhuang (Shenfu-Huanghua), which will be complemented by a third line connecting West Inner Mongolia, North Shaanxi, and East Ningxia with Caofeidian and Jingtang ports. As the hub port in this region, Tianjin also receives voluminous coal shipments from North Shanxi coal base via Fengda and Yuanping-Tianjin lines. Each seaport thus serves as a gateway for dedicated lines, such as Central Shanxi towards Qingdao (Shitai, Shide, Hanchang, Hanji, and Jiaoji lines) and East Shanxi, West Shanxi, and West Shandong towards Rizhao (Houyue, Taijiao, Xinshi, and Luliang lines). Lianyungang port is the southernmost loading seaport, as it transships coal from Huanglong base via the Longhai railway. Chinese authorities plan to 
further mine in East Inner Mongolia and develop Yingkou, Huludao, and Jinzhou loading ports as well as dedicated railway lines to ease the transportation of coal. Further mining in East Inner Mongolia should be backed by enlarging the capacity of loading (Yingkou, Huludao, and Jinzhou) and unloading ports as well as by constructing specialized railways between coalfields and loading ports.

The Yangtze River corridor collects coal from the upper reaches and distributes it to the lower reaches, i.e., from Henan, Huainan-Huaibei, and Shaanxi bases via Jiaoliu, Jingguang, Huainan (double track, electrified), and Ningxi lines up to Zhicheng, Wuhan, Wuhu, and Nanjing ports, and then by river shipping towards Shanghai, Ningbo, Zhoushan, Suzhou, Zhenjiang, Nantong, and Jiangyin. One current project is to electrify Jiaoliu and Ningxi lines while constructing a dedicated passenger line for Jingguang. Similar trends are observed along the canal corridor connecting West Shandong and Jining port, North Jiangsu and Pizhou port, Shaanxi and Xuzhou port (Longhai line) along the Grand Canal towards the Yangtze River Delta. Besides the need to dredge up waterways and add more coal berths, a Longhai passenger-dedicated line should vacate its capacity for the freight. The Xi River corridor connects the Yunnan-Guizhou coal base with Nanning and Guigang ports via Nankun and Lizhan railways, proceeds to Laibin port via Qiangui railway or Hongshui River, then transfers coal towards the Pearl River Delta through the Xi River waterway. The coalspecialized railway constructed from West Inner Mongolia to Jiangxi also fosters the development of coal-loading river ports, such as Jingzhou and Yueyang, and develops new branches of rail-water intermodal transportation.

Such combined systems clearly try to overcome the spatial mismatch between loading and unloading ports as well the deficit of certain regions. Main challenges include the need to construct new coal-dedicated berths along rivers and waterways and to modernize the existing ones. Indeed, higher capacity at northern loading ports (20-100 thousand tons) compared with southern unloading ports (10-20 thousand tons in Jiangsu, Zhejiang, and Shanghai) results in ship congestion, specifically at the latter unloading ports.

\section{Policies for improving coal logistics in China}

\subsection{Adjusting coal trade policy}

Policy is an important factor that influences coal trade and has profoundly influenced the 
spatial pattern of port coal traffic. In recent years, to ensure energy security, the Chinese government adjusted its trade policy to reduce coal exports and increase coal imports based on a quota system and the adjustment of coal exporting tariffs. From 1995 to 2003, several measures aimed at boosting coal exports in March 2001 ${ }^{6}$. The coal export rebate rate is heightened and railway construction fund is exempted on several lines (Daqin, Jingyuan, Fengda, and Jingqin) while port charges of exported coal are reduced in several ports (Yingkou, Qinhuangdao, Tianjin, Qingdao, Lianyungang, and Jingtang) and port construction funds are exempted. Furthermore, the loading fee of exported coal has been reduced from 18.7 Yuan RMB to 13 Yuan RMB per ton and the rail-loading fee in Qinhuangdao has also been cancelled. Such measures were followed up in March $2003^{7}$ to facilitate China's status as the world's second coal exporter. However, the focus of these preferential policies on northern railways and seaports resulted in the concentration of exported coal at the west coast of Bohai. This explains why the subsequent measures in 2004 tended to discourage coal exports ${ }^{8}$ through the allotment control.

As shown in Figure 10, coal export quotas gradually decreased over time, with the exception of 2011. Coal export tariffs were constantly adjusted. From 1995 onwards, China implemented a coal export taxation reimbursement system $^{9}$ by which the coal export rebate rate jumped from $3 \%$ to $9 \%$ in 1998 and to $13 \%$ in 1999 . However, in early 2004 , the export rebate rate of thermal coal and anthracite coal dropped to $11 \%$ and that of coking coal and coke to 5\%. From mid- 2004, the export of coke and coking coal abolished that policy while the export rebate rate for thermal coal and anthracite coal decreased to $8 \%$ in mid- 2005 . In late 2006, the coal export tax refund policy was cancelled completely ${ }^{10}$, as an export temporary tariffs rate was imposed on coke by $5 \%$ and extended to coking coal as well. From mid- 2008, this tariff was imposed on all kinds of coals at $10 \%$ level. Such measures have directly resulted in a rapid decrease of coal exports and related port traffics (see Figure 3).

The policy on coal imports tends to be more relaxed. From early 2005, the temporary rate of import tariff of coking coal was adjusted down to zero, and the thermal and anthracite coal

\footnotetext{
6 "Notice on the exemption of the export coal traffic from railway construction fund on four railway lines" and "Notice on the exemption of the export coal traffic from port construction fund and adjustment on its port charges"

7 "Circular on Extending the Period for Execution of the Policies on Encouraging Coal Export"

8 "Measures for the Administration of Quotas for Coal Export"

9 "Notice on Increasing the Taxation Reimbursement for Exported Coal, Steel, Cement and Ships and Boats"

10 "Circular on Adjusting Provisional Import and Export Tax Rate of a Part of Commodities"
} 
was levied by $6 \%$ and $3 \%$ of import tariffs. The import tariff for thermal coal decreased to $3 \%$ in mid- 2005 and to $1 \%$ in late 2006 , except for coking coal. This tariff was cancelled in mid2007. This policy caused the reduction of import costs and stimulated large-scale foreign imports at coastal provinces, such as Guangdong and Fujian, with imports surpassing exports from then onwards (see also Figure 3).

[Insert Figure 10 about here]

\subsection{Price comparison between domestic and international markets}

To some extent, the explosive growth of China's coal imports has been attributed to relatively lower prices on international coal markets. In addition, the consolidation of the coal industry by the rapid closure of small coal mines, which accounted for about $40 \%$ of China's coal production, is one temporary cause of the straight-line rise of China's domestic coal prices (Fang \& Victor, 2011; Leo, 2008; Rudolf, 2010). State-controlled contract prices for thermal coal have increased rapidly from 137 Yuan/ton in 2002 to current 537 Yuan/ton (Pan \& Zhang, 2003). Average prices of commercial coal have soared even more rapidly, from 168 Yuan/ton (\$20/t) in 2002 to current 837 Yuan/ton. Recently, domestic coal prices have even been 60 Yuan/ton higher on average compared to overseas markets (Pan \& Wang, 2010). In East China, the price of bituminous coal of $4800 \mathrm{kcal}$ soared from 200 to 320 Yuan/ton in early 2001, whereas the international coal market remained stable. For example, producing bituminous coal (4800 kcal) only reached \$20 US per ton, and even including transportation, tariff, and value-added tax costs, the final cost reached about 270-300 Yuan/ton. Therefore, China's domestic coal has no obvious price advantage, and this motivates many consumers to purchase foreign coal.

In 2004 and 2005, due to the influence of China's rapidly developing metallurgy and thermal power industries, the price of domestic coal continued to rise sharply, even more than international prices. In 2004, the Chinese government adjusted the import tariff of coking coal and bituminous coal; taking into account the CIF price of \$50 US and an exchange rate of 8 , the price of bituminous coal dropped by 12 Yuan/ton while coking coal reduced its cost to about 5716 Yuan/ton, as calculated using a CIF price of \$120 US. Since the 2008 global financial crisis, the coal demand of Germany, Japan, South Korea, and Taiwan fell sharply, thus causing great decrease in international coal prices. However, during the 
same period, China's coal price continued to rise, thus making coal imports cheaper compared to domestic coal, especially in the southeast region located away from production bases. After a record of $\$ 194.79$ US per ton for thermal coal in mid- 2008 by the world's largest coal loading port, Newcastle in Australia, prices continued to fall and reached only US\$ 80 per ton in early 2009 and \$76.75 US in mid-2009, as illustrated in Figure 11. Yet, the coal price for Qinhuangdao port is 580 Yuan/ton, and even when deducting shipping costs, domestic coal cost remains higher by 70-80 Yuan/ton compared to that of imported coal CIF. Such considerations increasingly motivate coal imports and further transform China from a net exporter into a net importer, although price is a short-term factor and has only a temporary influence on coal trade.

\section{[Insert Figure 11 about here]}

\subsection{Integration of coal industry}

In a context of changing economic and environmental contexts, the Chinese government has been promoting the consolidation of coal enterprises since 2002 (Shen, 2012). In early 2007, the "11th Five Year Plan of Coal Industry" started to restructure the coal industry by closing down small mines and controlling coal output amounts. Consolidation has already been completed in Shanxi and is now applied to Henan, Shaanxi, Shandong, Guizhou, and Inner Mongolia (Hook, 2011; Zhang, 2011). Through this plan, about 9000 small mines and 450 million tons of yearly production have been removed on average for safety purposes in order to reduce mine disasters, limit the outdated capacity of coal production, reduce the waste of coal reserves, protect the environment, and promote the modernization of production. Especially, Shanxi and Henan reduced their coal production capacity by 100 million tons. In October 2010, the State Council launched another policy ${ }^{11}$ through which over ten thousand coal-mining enterprises were reorganized. Because the concerned provinces are major coal producers, the integration led to the reduction of coal supply. As the largest coal consumer, Guangdong, withdrew completely from the coal mining industry and transferred coal from other provinces or countries, notably after the mining accident of Xingning in 2005 and as a remedy to coal shortage.

Before 2005, China's energy supply and price remained firmly under the control of the central

\footnotetext{
11 "Notice to speed up the merger and integration of coal mining enterprises"
} 
government. Coal and coal-fired electricity are typical up- and downstream industries where the transaction relationships occur via long-term inflexible contracts. In 2005, however, China cancelled the government-guided price to release the regulation of coal price and give more freedom to coal enterprises and power enterprises to autonomously bargain prices $(\mathrm{Qu}, 2006)$. Coal producers tried to increase prices but faced strong opposition from electric companies (Wang, 2007). This divergence leads power enterprises located in the coastal provinces to massively purchase and import foreign coal. For instance, Zhejiang Energy Group imported 1 million tons from Australia in 2006, and several enterprises in Guangdong, such as Guangdong Yudean Group, signed an annual coal contract of 7 million tons with Vietnam Coal Corporation in 2008. At the public bidding for Vietnamese coal export in 2009, most tenders were Chinese companies. Perhaps, after reaching sufficient integration of its coal industry, China shall restore the growth of coal output and might mitigate the explosive growth of coal imports.

More recently, Chinese companies have continued to invest and excavate foreign coal resources. MCC Overseas LTD, China Power International Development Limited, and Resource House Limited in Australia jointly developed a coal extraction in Queensland, which is projected to produce 30 million tons of thermal coal yearly from 2014. In 2009, China Huaneng Group purchased 51\% stake of PT Berau Coal in Indonesia and $25.5 \%$ of the Monto coal project in Australia. Another example is Yanzhou Coal Mining Company Limited that merged with Australia's Felix Resources in the late 2009, while China Investment Co. invested \$1.9 billion US in PT Bumi Resources Tbk, an Indonesian coal company. In addition, several sporadic factors also influenced the growth of coal imports. For instance, the reduction of waterpower in recent years that resulted from the drought of Southwest China stimulated thermo coal imports from Indonesia and Vietnam. The average daily capacity of waterpower in Guizhou province dropped by 33\%, and the current operational facilities in Yunnan province could not account for $30 \%$ of the installed capacity.

\subsection{Overburden of railway coal transport capacity and bottlenecks}

The spatial mismatch between coal supply and demand in China determined a long-term pattern that shapes the current distribution of flows and corridors (Kuby et al., 1995). While railways occupy about $60 \%$ of China's total coal traffic, the rapid growth of coal traffic put unprecedented pressures on the transport system. Coal traffic by rail increased from 0.53 
billion tons in 1986 to 1.8 billion tons in 2012, thereby increasing its share from $40.2 \%$ to $55.2 \%$ of total rail freight traffic. Major rail arteries are already overburdened. Moving coal across China utilizes a large and growing share of railway capacity. As of 2012, rail transported more than 1.69 billion metric tons of coal, accounting for more than half of total freight capacity. Currently, coal haulage confronts serious shortages of transport capacity and infrastructure, and major routes have run beyond their capacity, especially those connecting Inner Mongolia and Ningxia. The utilization rate of Daqin, Shitai, and Jingyuan routes has reached $120 \%, 114 \%$, and $105 \%$, respectively. The shortage of rail capacity influences directly the coal supply to South China, placing further constraints on power capacity and outages after 2003. As the amount of coal requiring transport grows, the construction of new routes towards the ports, development of local rail networks penetrating coal bases, and capacity enlargement of corridors did not solve this situation (Todd et al., 1997).

Indeed, one factor contributing to the recent rise in coal prices is the stress from the transport system (Rui et al., 2011; Zhou, 2010). Furthermore, depleting coalmines in the coastal region (e.g., Zhejiang) and reducing coal output (e.g., Shandong) exacerbated the need for coal supply. These factors compelled China to focus its overall development strategy on western regions. The rapid westward shift of coal production gravity increased both coal traffic volumes and transported distances. The average rail haul length for coal was 521.7 kilometers in 1986 but increased to 645 kilometers in 2012. Accordingly, the average cost per tonkilometer rose from 0.05 Yuan RMB to 0.16 Yuan RMB, thereby the transport costs reached over half of domestic coal cost in Southern China. Furthermore, shipping distances between Qinhuangdao and the Pearl River Delta, over 1000 nautical miles, exceed those of the ASEAN, so that no significant advantage comes from shipping coal from northern China compared to adjacent countries. The combination of the aforementioned factors promoted an unprecedented growth of coal imports by coastal provinces in the context of rapidly growing coal demand and energetic dependence (Ritschel, 2010). The future enlargement of railway capacity may not solve bottlenecks and change this situation (Minchener, 2004; Sagawa et al., 2007); instead, it shall mitigate the growth rate of imports. In particular, coal imports from Canada, South Africa, and Colombia mainly reflect a temporary phase caused by internal adjustments in coal policies and logistics. 


\section{Discussion and conclusion}

Due to the dominant role of coal in the structure of its energy consumption and to the uneven distribution of coal resources between inland and coastal regions, China is currently confronted with the need to optimize related interregional transfers. While the coastal region has only poor coal reserves, its large-scale population and industries demand enormous coal volumes to live and operate. However, coastal provinces are confronted with an increasing shortage of coal resources, as power rationing had seriously affected their sustainable development. The spatial mismatch between coal demand and supply as well as increased costs extended the travelled distances of coal flows domestically. Although a coal transfer network has emerged, continuous shortfalls in the coastal region urge China to improve this network and enhance its transport capacity. One important approach is to enhance railway corridors connecting major coalfields by upgrading the existing railway, building dedicated lines for freight, and facilitating intermodal transfers between rail and water systems. Other solutions include building mine-mouth thermal power plants to limit coal transfers and foster electricity transmission directly to the coastal region, relegate energy-intensive industries to reduce coal consumption, and regulate China's energy structure through developing new energy sources. Yet, such policy directions should not ignore wider issues of coal trade and pricing and their effect on local dynamics.

As a large country with extended coal resources distribution, production, and consumption, China's self-produced coal has sufficiently covered domestic demand. Following a period of slow growth, coal import volumes increased rapidly over the recent decade, especially since 2008, while coal exports have greatly declined after 2003. Such trends transformed China from net exporter to net importer around the year 2009. Meanwhile, ports became the key nodes for exports within the coal trade network, notably along the western Bohai rim and southern Shandong peninsula. Before the late 1990s, coal imports concentrated at southeastern seaports, but subsequently, northern ports also started to import coal on a massive scale. Coal trade partners long remained adjacent countries for imports (i.e., Japan, Korea, and Taiwan) and exports (Indonesia, Australia, and North Korea) due to short shipping distances. Internally, the coal transfer network witnessed a gradual hinterland expansion as well as an increase in the number of coal ports and the development of an integrated system of unloading, reloading, reshipping, or transit. In China, the spatial mismatch between the respective location of coal demand and coal resources, distribution, and production indicated 
that coastal regions mainly relied on coal transfers from inland regions. The rapid expansion of heavy and chemical industries since the late 1990s stimulated coal consumption in the coastal region, but in parallel, the restructuring of the coal industry in the 2000s led to a reduction of coal production. These factors caused the shortage of coal supply in the coastal region. Furthermore, the tightening of coal export policies and the relaxation of coal import policies, combined with increased complexity of thermal coal contracts and the shortage of railway transport capacity, fostered large-scale coal imports at coastal provinces. Nowadays, energy-intensive industries in the coastal region are still expanding, producing increasing demand for coal. Several measures, however, shall remedy this situation, such as the readjustment of the industrial structure, domestic coal pricing, energy conservation and emissions reduction, and expansion of railway capacity. Although coal imports will remain at high levels in the next years to come, their growth rate will inevitably slow down.

\section{Acknowledgements}

This research was supported by the Natural Science Foundation of China (Project No. 41171108).

\section{References}

Ash, L. Waters, C. D. J., 1991. Simulating the transport of coal across Canada-strategic route planning. Journal of the Operational Research Society 42(3), 195-203.

Chan, H. L., Lee, S. K., 1997. Modelling and forecasting the demand for coal in China. Energy Economics 19, 271-287.

Chang, C., Miles, R. D., Sinha, K. C., 1980. A regional railroad network optimization model for coal transportation. Transportation Research Part B: Methodological 15(4), 227-238.

Cheng, S., Xu, Z., Shen, L., 2008. Spatial-temporal process and driving force of interprovincial coal flowing in China. Acta Geographica Sinica 63(6), 603-612.

Chinese Academy of Engineering, 2011. China's Energy and Long-term Development Strategy (2030-2050). Beijing: Science Press.

Crompton, P., Wu, Y. R., 2005. Energy consumption in China: Past trends and future directions. Energy Economics 27, 195-208.

Dorian, J. P., 2005. Central Asia: A major emerging energy player in the 21st century. Energy Policy 34, 544-555.

Ekawan, R., Duchene, M., 2006. The evolution of hard coal trade in the Atlantic market. Energy Policy 34, 1487-1498.

Elmes, G., 1984. Coal transportation: An undervalued aspect of energy modeling? Transportation Research Part A: General 18(1), 13-23.

Fan, J., 1997. Coordination of exploitation of energy resources and development of regional economy. Journal of Natural Resources 12(4), 349-356 (in Chinese).

Huenemann, R. W., 1984. The Dragon and the Iron Horse: The Economies of Railroads in China 1876-1937. Harvard University Press, Cambridge, MA.

Kania, J. J., 1984. Economics of coal transport by slurry pipeline versus unit train: A case study. Energy Economics 6(2), 131-138. 
Kuby, M., Ratick, S., Osleeb, J., 1991. Modeling U.S. coal export planning decisions. Annals of the Association of American Geographers 81, 627-649.

Kuby, M., Shi, Q., Thawat, W., Sun, X., Xie, Z., Cao, W., Zhang, C., Zhou, D., Yu, X., Cook, P., Friesz, T., Neuman, S., Lin, F., Rong, Q., Wang, X., Gao, S., 1995. Planning China's coal and electricity delivery system. Interfaces 25(1), 41-68.

Kuby, M., Xu, Z., Xie, X., 2001, Railway network design with multiple project stages and time sequencing. Journal of Geographical Systems 3, 25-47.

Kuby, M., He, C., Trapido-Lurie, B., Moore, N., 2011. The changing structure of energy supply, demand, and $\mathrm{CO} 2$ emissions in China. Annals of the Association of American Geographers 101, 795-805.

LeBlanc, M. R., Kalter, R. J., Boisvert, R. N., 1978. Allocation of United States coal production to meet future energy needs. Land Economics 54(3), 316-336.

Lei, Z., 2002. Energy security and resources internationalization. Resources Science 24(1), 14 (in Chinese).

Li, J. K., 2012. Strategic Reserve of Coal Resources in China and Regulation Mechanism. Beijing: Economic Management Press (in Chinese).

Lin, B., Q., Liu, J. H., 2010. Estimating coal production peak and trends of coal imports in China. Energy Policy 38, 512-519.

Lin, B., Yao, X., 2009. Optimization of thermal power plants and energy transport networks. Economic Research 6, 105-116 (in Chinese).

Liu, Y., 1999. Measures for problems of energy issues and supply in coastal region. Acta Geographica Sinica 54(6), 509-517 (in Chinese).

Ma, H. Y., Oxley, L., Gibson, J., Kim, B., 2008. China's energy economy: Technical change, factor demand and interfactor/interfuel substitution. Energy Economics 30, 2167-2183.

Ma, B., Lu, C., Lei, Z., 2009. The assessment of coal resources and its developing strategy in China. Resources Science 31(2), 224-230 (in Chinese).

Ma, J., 2008. The transport division of railway and water for major coal bases in China. Railway Engineering 6, 20-23 (in Chinese).

Ministry of Land and Resources, 2009. National Mineral Resources Planning (2008-2015). Resources and Environment 4, 17-20 (in Chinese).

Paulus, M., Trüby, J., 2011. Coal lumps vs. electrons: How do Chinese bulk energy transport decisions affect the global steam coal market? Energy Economics 33, 1127-1137.

Li, R., Leung, G. C. K., 2012. Coal consumption and economic growth in China. Energy Policy 40, 438-443.

Ritschel, W., 2009. Annual Report 2008/09. German Coal Importers' Association.

Ritschel, W., 2010. Annual Report 2010. German Coal Importers' Association.

Sagawa, A., Koizumi, K., 2007. Present state and outlook of China's coal industry. Technical Report, Institute of Energy Economics, Japan.

Shealy, M., Dorian, J.P., 2010. Growing Chinese coal use: Dramatic resource and environmental implications. Energy Policy 38, 2116-2122.

Shen, L., Gao, T. M., Xin, C., 2012. China's coal policy since 1979: A brief overview. Energy Policy 40, 274-281.

Shen, L., Philip, A. S., 2001. Economic analysis of reform policies for small coal mines in China. Resources Policy 27, 247-254.

Shiu, A., Lam, P. L., 2004. Electricity consumption and economic growth in China. Energy Policy 32(1), 47-54.

Sinton, J. E., Levine, M. D., Qingyi, W., 1998. Energy efficiency in China: accomplishments and challenges. Energy Policy 26(11), 813-829.

Smil, V., 1998. China's energy and resource uses: continuity and change. The China Quarterly $156,935-951$. 
Sun, P., Gu, X., 2005. Decomposition analysis of Chinese energy consumption. Resources Science 27(5), 16-19 (in Chinese).

Tang, Y., 2008. The pattern of China's coal resource consumption and its price developing mechanism. Resources Science 30(4), 554-560 (in Chinese).

Tao, Z., Li, M., 2007. What is the limit of Chinese coal supplies: a STELLA model of Hubbert Peak. Energy Policy 35, 3145-3154.

Todd, D., 1997. China's energy needs, coal transfers and the ports sector. Geoforum 28(1), 3953.

Todd, D., Jin, F.J., 1997. Interregional coal flows in China and the problem of transport bottlenecks, upholding the rail option. Applied Geography 17(3), 216-230.

Todd, D., Lei, Z., 1994. Ports and coal transfer: hug of China's energy supply policy. Energy Policy 22(7), 609-621.

Todd, D., Lei, Z., 1994. Regional policy grounded in minerals exploitation: A Chinese example. Resources Policy 20(1), 5-13.

Vaninetti, J., McKevitt, M., 1995. Coal transportation asserts a larger role. Coal 100(7), 3132.

Wang, C., Mo, H., Wang, J., 2009. Regularity and pattern of Chinese coal resources flow field. Journal of Natural Resources 24(8), 1402-1411 (in Chinese).

Wu, Y., Huang, S., 2008. The policy and optimization of coal logistics networks in China. China Coal 34(10), 27-30 (in Chinese).

Yuan, J. H., Kang, J. G., Zhao, C. H., Hu, Z. G., 2008. Energy consumption and economic growth: Evidence from China at both aggregated and disaggregated levels, Energy Economics 30, 3077-3094. 


\begin{tabular}{|c|c|c|c|}
\hline Type & $2008 / 10^{4}$ tons & $2009 / 10^{4}$ tons & $2012 / 10^{4}$ tons \\
\hline Total & 4078 & 12583 & 28779 \\
\hline Coking coal & 686 & 3442 & 5355 \\
\hline Steaming coal & 982 & 3803 & 10100 \\
\hline Anthracite & 1939 & 3433 & 5421 \\
\hline Others & 471 & 1905 & 7903 \\
\hline
\end{tabular}

Table 1: Nature of China's imported coal, 2008-2012

\begin{tabular}{|c|c|c|c|}
\hline \multicolumn{2}{|c|}{ Region } & $\begin{array}{c}\text { Installed capacity of } \\
\text { thermal power/ 10000kw }\end{array}$ & $\begin{array}{c}\text { Output of thermal } \\
\text { power/ 100 million kwh }\end{array}$ \\
\hline \multirow{4}{*}{ Mainland China } & 76834 & 39003 \\
\cline { 2 - 4 } & Subtotal & 37392 & 19675 \\
\cline { 2 - 4 } & \% & 48.67 & 50.44 \\
\cline { 2 - 4 } & Beijing & 514 & 258 \\
\cline { 2 - 4 } region & Tianjin & 1083 & 612 \\
\cline { 2 - 4 } & Hebei & 3810 & 2151 \\
\cline { 2 - 4 } & Liaoning & 2851 & 1316 \\
\cline { 2 - 4 } & Shanghai & 1943 & 1022 \\
\cline { 2 - 4 } & Jiangsu & 6480 & 3731 \\
\cline { 2 - 4 } & Zhejiang & 4626 & 2343 \\
\cline { 2 - 4 } & Fujian & 2510 & 1272 \\
\cline { 2 - 4 } & Shandong & 6448 & 3129 \\
\cline { 2 - 4 } & Guangdong & 5635 & 3046 \\
\cline { 2 - 4 } & Guangxi & 1177 & 158 \\
\hline
\end{tabular}

Table 2: Capacity and output of thermal power in the coastal region, 2012 


\begin{tabular}{|c|c|c|c|c|c|c|c|c|c|c|c|c|}
\hline & & Shanxi & $\begin{array}{c}\text { Inner } \\
\text { Mongolia }\end{array}$ & Heilongjiang & Anhui & Shandong & Henan & Guizhou & Yunnan & Shaanxi & Ningxia & Xinjiang \\
\hline \multirow{3}{*}{2006} & $\begin{array}{c}\text { Thermal power } \\
\text { generation/100 million } \\
\mathrm{kW} . \mathrm{h}\end{array}$ & 1502.5 & 1397.1 & 629.7 & 721.2 & 2269.5 & 1502.3 & 785.0 & 405.1 & 533.7 & 374.2 & 302.3 \\
\hline & $\begin{array}{l}\text { Thermal power coal } \\
\text { consumption/million } \\
\text { tons }\end{array}$ & 69.7 & 84.0 & 37.0 & 34.6 & 109.3 & 81.0 & 40.0 & 27.4 & 28.3 & 18.3 & 15.5 \\
\hline & $\begin{array}{l}\text { As percentage of total } \\
\text { coal production } / \%\end{array}$ & 12.0 & 28.2 & 36.0 & 41.5 & 77.7 & 41.5 & 33.9 & 37.3 & 17.5 & 56.0 & 34.3 \\
\hline \multirow{6}{*}{2012} & $\begin{array}{c}\text { Installed power- } \\
\text { generating capacity of } \\
\text { thermal power/ million } \\
\text { kilowatts }\end{array}$ & 50.1 & 60.2 & 17.5 & 32.2 & 68.2 & 53.6 & 21.9 & 13.9 & 22.3 & 16.4 & 22.6 \\
\hline & $\begin{array}{c}\text { Thermal power } \\
\text { generation/100 million } \\
\mathrm{kW} . \mathrm{h}\end{array}$ & 2454 & 3029 & 772 & 1767 & 3241 & 2465 & 1046 & 480 & 1149 & 952 & 998 \\
\hline & $\begin{array}{c}\text { Growth percentage of } \\
\text { thermal power } \\
\text { generation } / \%\end{array}$ & 63.3 & 116.8 & 22.6 & 145.0 & 42.8 & 64.1 & 33.3 & 18.5 & 115.3 & 154.4 & 230.1 \\
\hline & $\begin{array}{l}\text { Thermal power coal } \\
\text { consumption/million } \\
\text { tons }\end{array}$ & 108.4 & 202.3 & 42.6 & 75.4 & 132.8 & 113.9 & 40.3 & 30.8 & 41.6 & 46.3 & 49.7 \\
\hline & $\begin{array}{c}\text { Growth percentage } \\
\text { thermal power coal } \\
\text { consumption } / \%\end{array}$ & 55.5 & 140.7 & 15.2 & 118.2 & 21.5 & 40.7 & 0.8 & 12.7 & 46.8 & 152.3 & 220.9 \\
\hline & $\begin{array}{l}\text { As percentage of total } \\
\text { coal production } / \%\end{array}$ & 11.9 & 19.4 & 46.7 & 50.1 & 75.1 & 71.8 & 22.3 & 29.7 & 8.9 & 53.8 & 32.3 \\
\hline
\end{tabular}

Table 3: Capacity of mine-mouth power in China's coal bases, 2006 and 2012 


\begin{tabular}{|c|c|c|c|c|c|c|c|}
\hline Province & $\begin{array}{c}\text { Basic } \\
\text { coal } \\
\text { reserves } \\
(\%)\end{array}$ & $\begin{array}{c}\text { GDP } \\
(\%)\end{array}$ & $\begin{array}{c}\text { Population } \\
(\%)\end{array}$ & $\begin{array}{c}\text { Coal } \\
\text { output } \\
(\%)\end{array}$ & $\begin{array}{c}\text { Thermal } \\
\text { coal } \\
\text { million } \\
\text { tons })\end{array}$ & $\begin{array}{c}\text { Thermal coal/ } \\
\text { coal } \\
\text { consumption } \\
(\%)\end{array}$ & $\begin{array}{c}\text { As percentage } \\
\text { of total energy } \\
\text { consumption/\% }\end{array}$ \\
\hline Beijing & 0.16 & 3.10 & 1.54 & 0.12 & 6.5 & 28.68 & 1.62 \\
\hline Tianjin & 0.13 & 2.24 & 1.05 & 0.00 & 27.6 & 56.93 & 1.85 \\
\hline Hebei & 1.72 & 4.61 & 5.41 & 2.83 & 95.8 & 31.66 & 6.83 \\
\hline Shanxi & 39.52 & 2.10 & 2.68 & 21.96 & 108.4 & 23.53 & 4.36 \\
\hline Inner & 17.47 & 2.75 & 1.85 & 25.05 & 202.3 & 48.83 & 4.46 \\
\hline Mongolia & 1.39 & 4.31 & 3.26 & 1.59 & 62.7 & 38.08 & 5.31 \\
\hline Liaoning & 0.43 & 2.07 & 2.04 & 1.52 & 36.8 & 30.20 & 2.13 \\
\hline Jilin & 2.68 & 2.37 & 2.84 & 2.19 & 42.6 & 25.00 & 2.88 \\
\hline Heilongjiang & 0.00 & 3.50 & 1.77 & 0.00 & 34.0 & 73.14 & 2.56 \\
\hline Shanghai & 0.47 & 9.38 & 5.88 & 0.51 & 157.2 & 61.90 & 6.51 \\
\hline Jiangsu & 0.02 & 6.01 & 4.06 & 0.00 & 86.3 & 61.86 & 4.08 \\
\hline Zhejiang & 3.50 & 2.99 & 4.44 & 3.62 & 75.4 & 44.20 & 2.56 \\
\hline Anhui & 0.19 & 3.42 & 2.78 & 0.49 & 45.0 & 54.55 & 2.52 \\
\hline Fujian & 0.18 & 2.25 & 3.34 & 0.71 & 26.5 & 43.80 & 1.63 \\
\hline Jiangxi & 3.47 & 8.67 & 7.19 & 4.25 & 132.8 & 32.15 & 8.78 \\
\hline Shandong & 4.31 & 5.13 & 6.98 & 3.82 & 113.9 & 36.98 & 5.34 \\
\hline Henan & 0.14 & 3.86 & 4.29 & 0.21 & 34.5 & 24.39 & 3.99 \\
\hline Hubei & 0.29 & 3.84 & 4.93 & 2.17 & 32.3 & 27.88 & 3.78 \\
\hline Hunan & 0.91 & 68.16 & 6.58 \\
\hline Guangdong & 0.01 & 9.90 & 7.86 & 0.00 & 111.1 & 2.07 \\
\hline Guangxi & 0.09 & 2.26 & 3.47 & 0.18 & 27.7 & 41.62 & 2.07 \\
\hline Hainan & 0.05 & 0.50 & 0.66 & 0.00 & 6.9 & 74.29 & 0.38 \\
\hline Chongqing & 0.86 & 1.98 & 2.18 & 0.86 & 14.1 & 21.47 & 2.09 \\
\hline Sichuan & 2.37 & 4.14 & 5.99 & 2.28 & 25.5 & 21.46 & 4.64 \\
\hline Guizhou & 3.02 & 1.19 & 2.58 & 4.35 & 40.3 & 27.17 & 2.23 \\
\hline Yunnan & 2.57 & 1.79 & 3.46 & 2.50 & 30.8 & 31.32 & 2.35 \\
\hline Tibet & 0.01 & 0.12 & 0.23 & 0.00 & 0.0 & & 0.00 \\
\hline Shaanxi & 4.74 & 2.51 & 2.78 & 11.24 & 41.6 & 25.15 & 2.40 \\
\hline Gansu & 1.48 & 0.98 & 1.91 & 1.17 & 34.5 & 54.48 & 1.58 \\
\hline Qinghai & 0.69 & 0.33 & 0.43 & 0.63 & 6.0 & 25.02 & 0.80 \\
\hline Ningxia & 1.41 & 0.41 & 0.48 & 2.07 & 46.3 & 49.78 & 1.03 \\
\hline Xinjiang & 6.63 & 1.30 & 1.66 & 3.70 & 49.7 & 41.19 & 2.67 \\
\hline & & & & & & & \\
\hline
\end{tabular}

Table 4: Provincial comparison of coal reserves, coal output, thermal coal, population, and GDP in 2012 


\begin{tabular}{|c|c|c|c|c|c|c|}
\hline \multirow{2}{*}{ Country } & \multicolumn{2}{|c|}{2005} & \multicolumn{2}{c|}{2008} & \multicolumn{2}{c|}{2012} \\
\cline { 2 - 7 } & Tons & $\%$ & Tons & $\%$ & Tons & $\%$ \\
\hline Indonesia & 2.44 & 9.31 & 19.12 & 22.48 & 118 & 41 \\
\hline Vietnam & 10.2 & 38.92 & 7.17 & 8.43 & 17 & 5.91 \\
\hline Australia & 5.89 & 22.47 & 41.83 & 49.18 & 59.46 & 20.67 \\
\hline Russia & 0.94 & 3.59 & 11.02 & 12.96 & 20 & 6.95 \\
\hline Mongolia & 2.54 & 9.69 & 1.96 & 2.30 & 22 & 7.64 \\
\hline South Africa & & & & & 14 & 4.86 \\
\hline North Korea & 2.8 & 10.68 & 1.06 & 1.25 & 12 & 4.17 \\
\hline Others & 1.4 & 5.34 & 2.89 & 3.40 & 25.33 & 8.8 \\
\hline Total & 26.21 & 100 & 85.05 & 100 & 287.79 & 100 \\
\hline
\end{tabular}

Table 5: Major coal exporters to China, 2005-2012 (Unit: million tons, \%)

\begin{tabular}{|c|c|c|c|}
\hline Year & $\begin{array}{c}\text { Coal } \\
\text { traffic/million } \\
\text { tons }\end{array}$ & $\begin{array}{c}\text { Coal ton-kilometers/ } \\
\text { billion tons- } \\
\text { kilometers }\end{array}$ & $\begin{array}{c}\text { Average transport } \\
\text { distance/kilometers }\end{array}$ \\
\hline 1993 & 659.4 & 370.0 & 56.1 \\
\hline 1994 & 673.6 & 377.7 & 56.1 \\
\hline 1995 & 673.6 & 377.7 & 56.1 \\
\hline 1996 & 720.6 & 404.8 & 56.2 \\
\hline 1997 & 703.5 & 389.4 & 55.4 \\
\hline 1998 & 640.8 & 354.3 & 55.3 \\
\hline 1999 & 649.2 & 357.1 & 55.0 \\
\hline 2000 & 685.5 & 380.6 & 55.5 \\
\hline 2001 & 766.3 & 427.6 & 55.8 \\
\hline 2002 & 818.5 & 463.9 & 56.7 \\
\hline 2003 & 881.3 & 505.5 & 57.4 \\
\hline 2004 & 992.1 & 571.3 & 57.6 \\
\hline 2005 & 1070.8 & 637.4 & 59.5 \\
\hline 2006 & 1120.3 & 672.8 & 60.1 \\
\hline 2007 & 1220.8 & 741.6 & 60.7 \\
\hline 2008 & 1343.3 & 836.0 & 62.2 \\
\hline 2009 & 1327.2 & 847.8 & 63.9 \\
\hline 2010 & 1560.2 & 1001.6 & 64.2 \\
\hline 2011 & 1721.3 & 1124.7 & 65.3 \\
\hline 2012 & 1685.2 & 1087.4 & 64.5 \\
\hline & & & \\
\hline
\end{tabular}

Table 6: Coal traffic and coal ton-kilometers by railway in China, 1993-2012 


\begin{tabular}{|c|c|c|c|c|c|c|}
\hline \multirow{2}{*}{ Region } & \multirow{2}{*}{$\begin{array}{c}\text { No. } \\
\text { berths }\end{array}$} & \multicolumn{2}{|c|}{ Unloading capacity/10 $0^{4}$ tons } & \multirow{2}{*}{$\begin{array}{c}\text { Unloading } \\
\text { traffic/10 }\end{array}$} & Utilization rate \\
\cline { 3 - 6 } & & Total & Public & Owner & & \\
\hline $\begin{array}{c}\text { Yangtze River } \\
\text { Delta }\end{array}$ & 50 & 15219 & 3190 & 12029 & 21563 & 1.42 \\
\hline Southeast Fujian & 9 & 2575 & 230 & 2345 & 2492 & 0.97 \\
\hline Pearl River Delta & 17 & 7500 & 3170 & 4330 & 7985 & 1.06 \\
\hline Beibu Gulf & 4 & 930 & & 930 & 764 & 0.82 \\
\hline Total & 80 & 26224 & 6590 & 19634 & 32804 & 1.25 \\
\hline
\end{tabular}

Table 7: Coal unloading capacity of major coastal regions, 2012

\begin{tabular}{|c|c|c|c|c|c|c|}
\hline Coal base & $\begin{array}{l}\text { proven } \\
\text { reserves } / 10^{8} \\
\text { tons }\end{array}$ & $\begin{array}{l}\text { Coal } \\
\text { output } / 10^{8} \\
\text { tons }\end{array}$ & $\begin{array}{c}\text { Transport } \\
\text { demand by } \\
\text { rail } / 10^{8} \\
\text { tons }\end{array}$ & Railway lines & Major destination & $\begin{array}{c}\text { capacity } / 10^{8} \\
\text { tons }\end{array}$ \\
\hline North Shanxi & 7000 & 3.3 & 2.9 & $\begin{array}{c}\text { Daqin, } \\
\text { Fengshada, Jitong }\end{array}$ & $\begin{array}{c}\text { Qinhuangdao } \\
\text { port, } \\
\text { Tianjin port } \\
\end{array}$ & 4 \\
\hline Shendong & 1066 & 1.8 & 1.6 & Shenhuang & Huanghua port & 2 \\
\hline Central Shanxi & 1680 & 2.4 & 2.1 & $\begin{array}{c}\text { Shitai, Houyue, } \\
\text { Hanchang, } \\
\text { Jingyuan }\end{array}$ & Tianjin port & 2.3 \\
\hline East Shanxi & 120 & 2.0 & 1.15 & $\begin{array}{c}\text { Taijiao, } \\
\text { Hanchang, Hanji }\end{array}$ & East China & 1.3 \\
\hline Shaanxi & N/A & 2.0 & 1.8 & $\begin{array}{l}\text { Longhai, Houxi, } \\
\text { Ningxi, Xikang }\end{array}$ & $\begin{array}{c}\text { Lianyungang port } \\
\text { Yangtze River } \\
\text { Delta }\end{array}$ & 2.2 \\
\hline Henan & 180 & 1.5 & 1.28 & $\begin{array}{c}\text { Jingguang, } \\
\text { Jiaozhi }\end{array}$ & $\begin{array}{l}\text { Central China } \\
\text { South China }\end{array}$ & 1.3 \\
\hline $\begin{array}{c}\text { West } \\
\text { Shandong }\end{array}$ & 405 & 1.9 & 1.77 & Xinshi, Jinghu & $\begin{array}{c}\text { Rizhao port } \\
\text { Yangtze River } \\
\text { Delta }\end{array}$ & 2 \\
\hline $\begin{array}{l}\text { Huainan- } \\
\text { Huaibei }\end{array}$ & 500 & 1.3 & 1.1 & Jinghu, Huainan & $\begin{array}{l}\text { Yangtze River } \\
\text { Delta }\end{array}$ & 1.2 \\
\hline $\begin{array}{c}\text { Yunnan and } \\
\text { Guizhou }\end{array}$ & 530 & 2.5 & 1.77 & $\begin{array}{c}\text { Nankun, Zhuliu, } \\
\text { Qiangui }\end{array}$ & South China & 2 \\
\hline $\begin{array}{l}\text { Middle-West } \\
\text { of Inner } \\
\text { Mongolia }\end{array}$ & 3000 & 14.5 & - & Menghua & Central China & 2 \\
\hline
\end{tabular}

Table 8: Production and railway connection of Chinese coal regions, 2012 

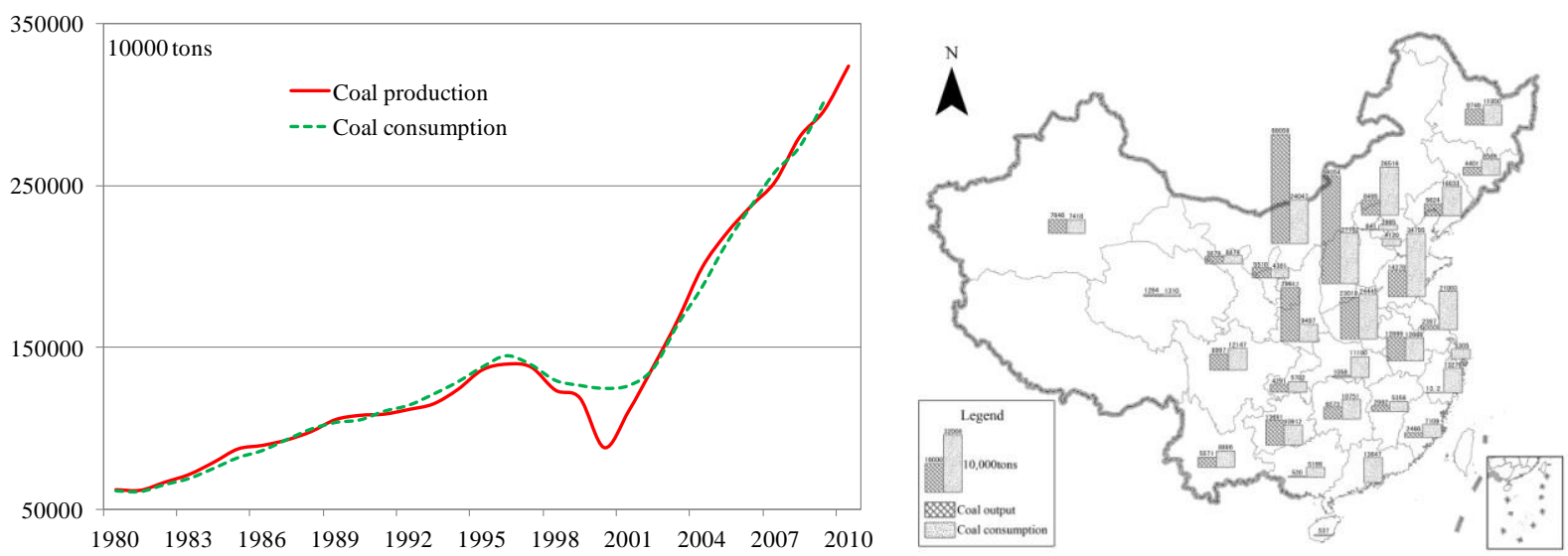

Figure 1: Evolution (1980-2010) and distribution (2007) of coal output and consumption in China
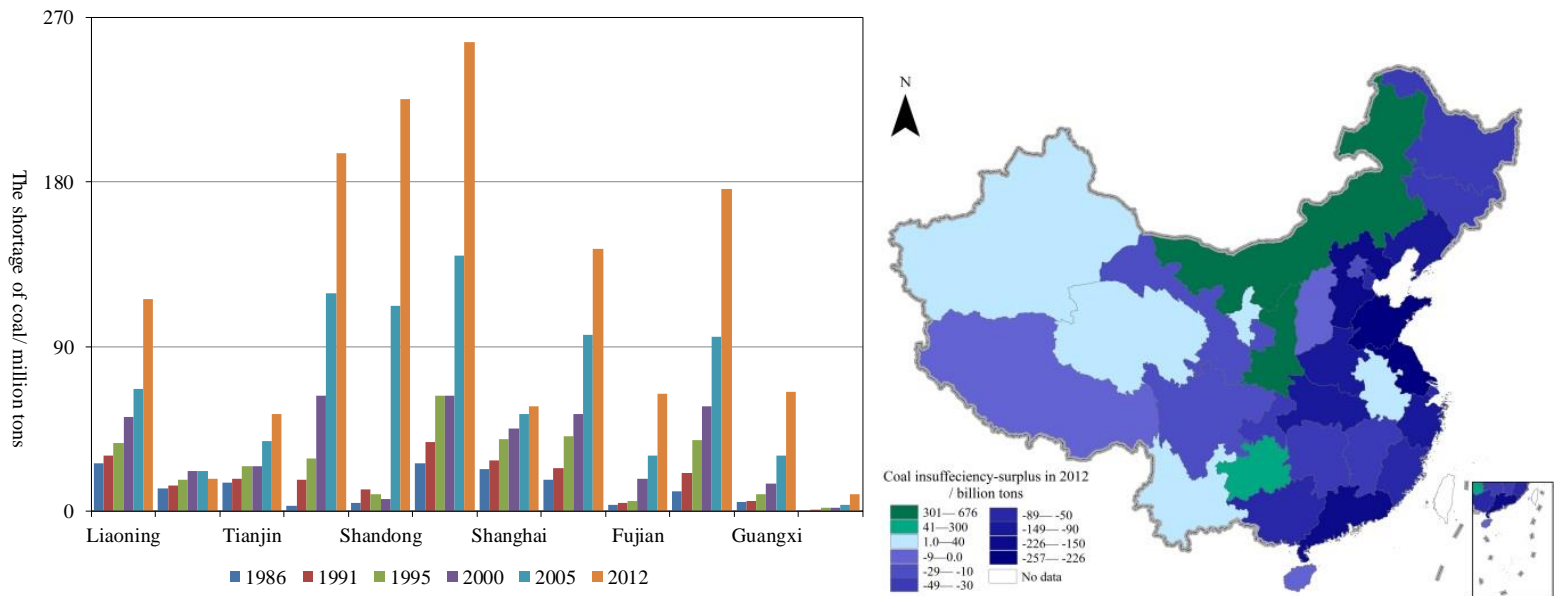

Figure 2: Coal shortage evolution among coastal provinces (1986-2012) and distribution (2012)
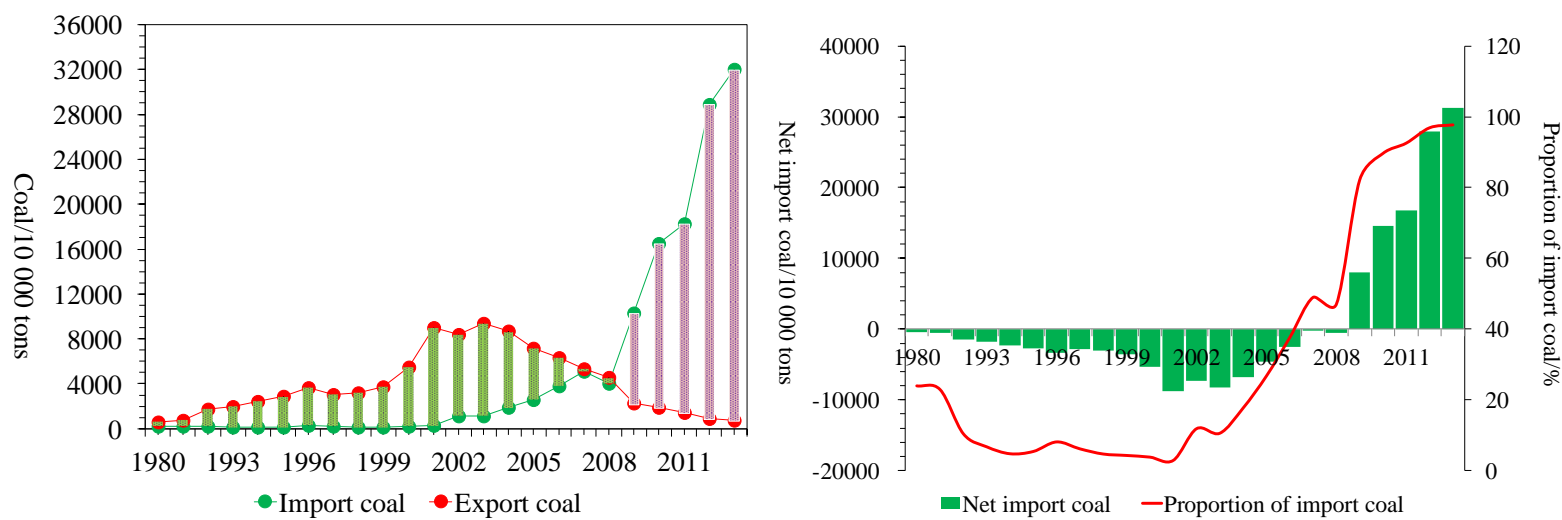

Figure 3: Evolution of coal trade (1980-2012) and net imported coal (1980-2012) 

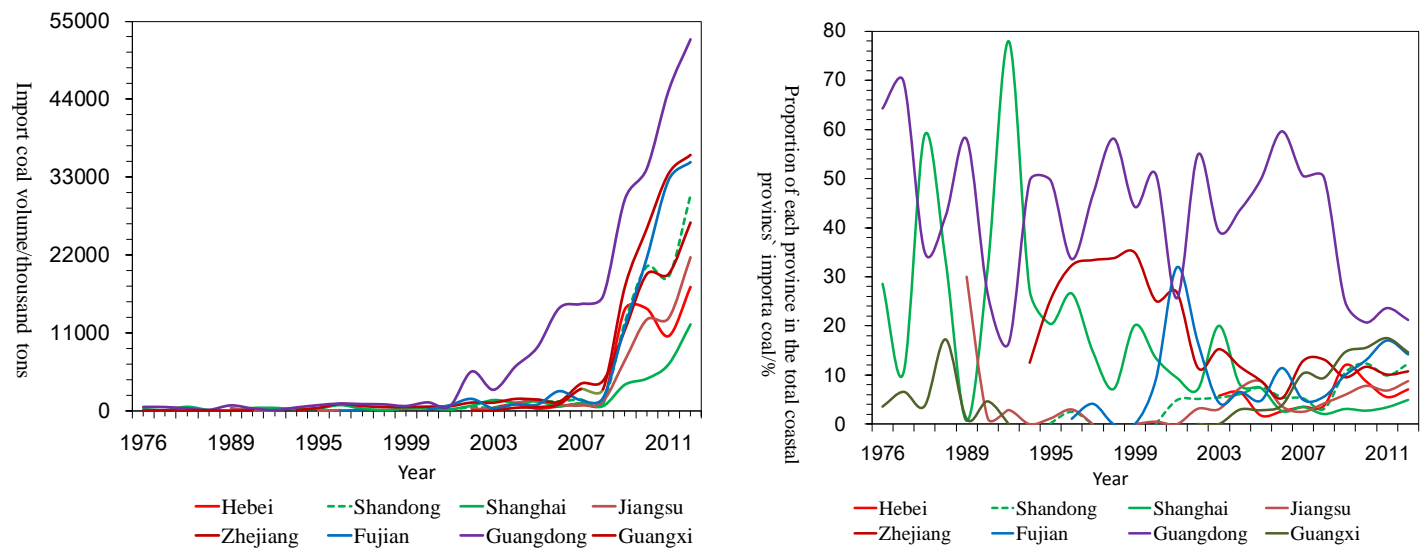

Figure 4: Imported coal evolution and distribution by province (1976-2012)

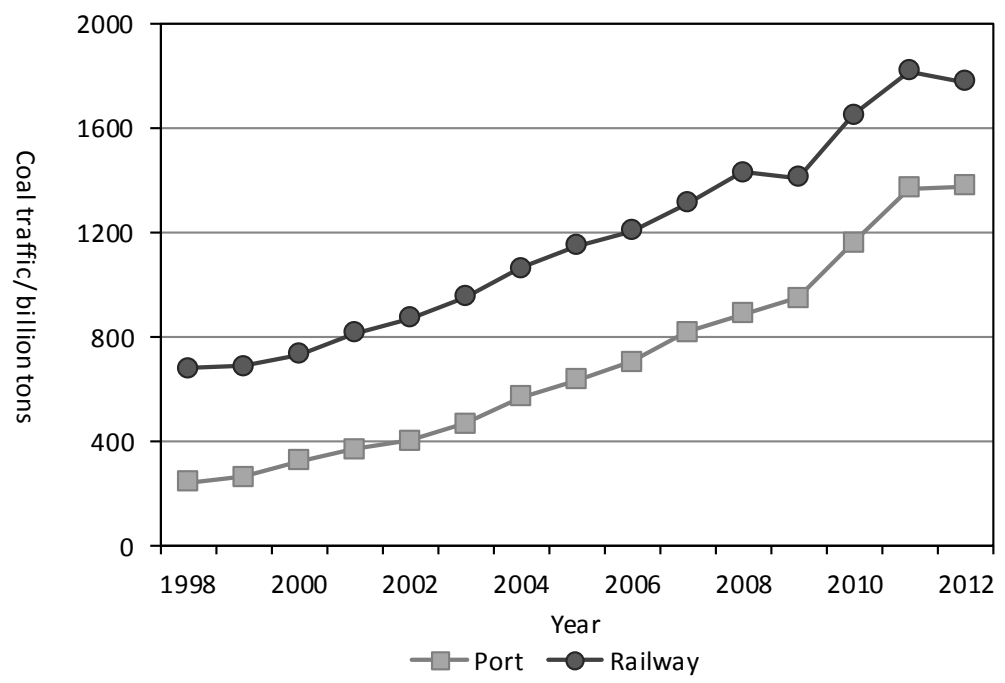

Figure 5: Coal traffic by railway and port in China, 1998-2012 

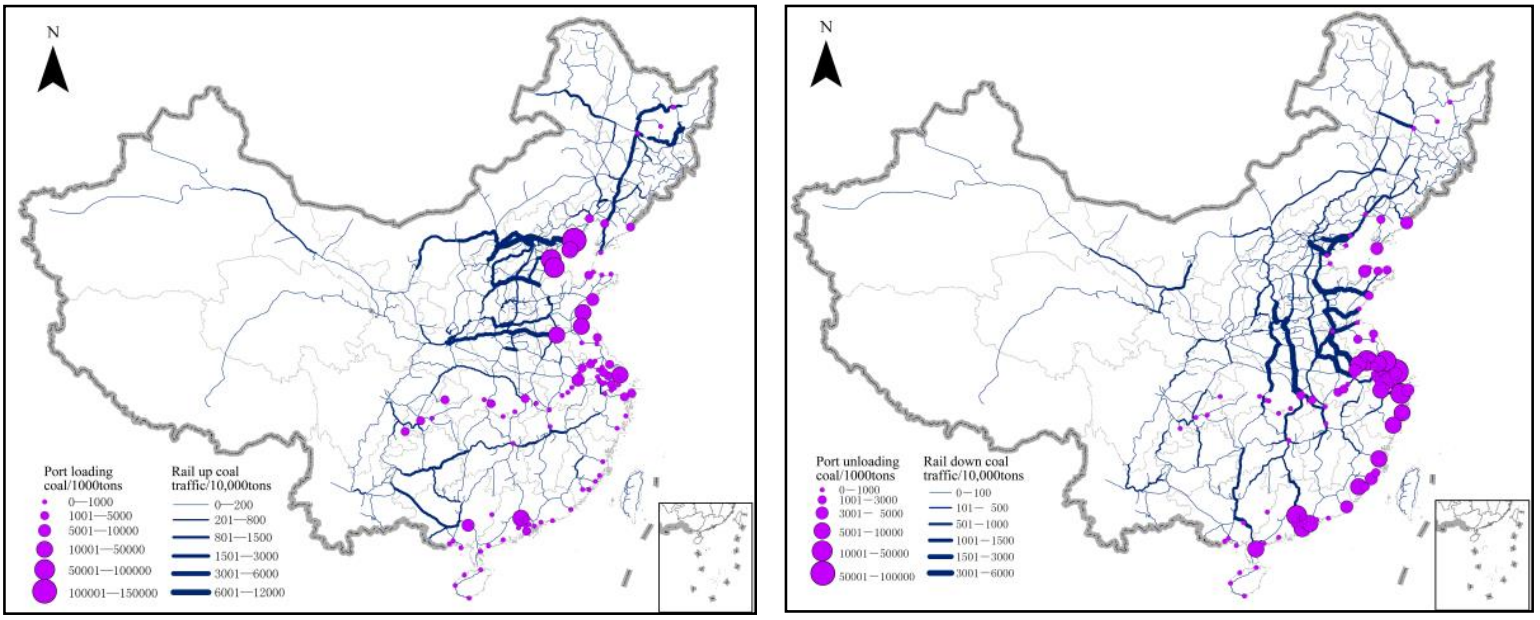

Figure 6: Spatial pattern of rail-sea coal transport in China, 2012

N.B. rail-up accounts for towards "Beijing", rail-down for "from Beijing"

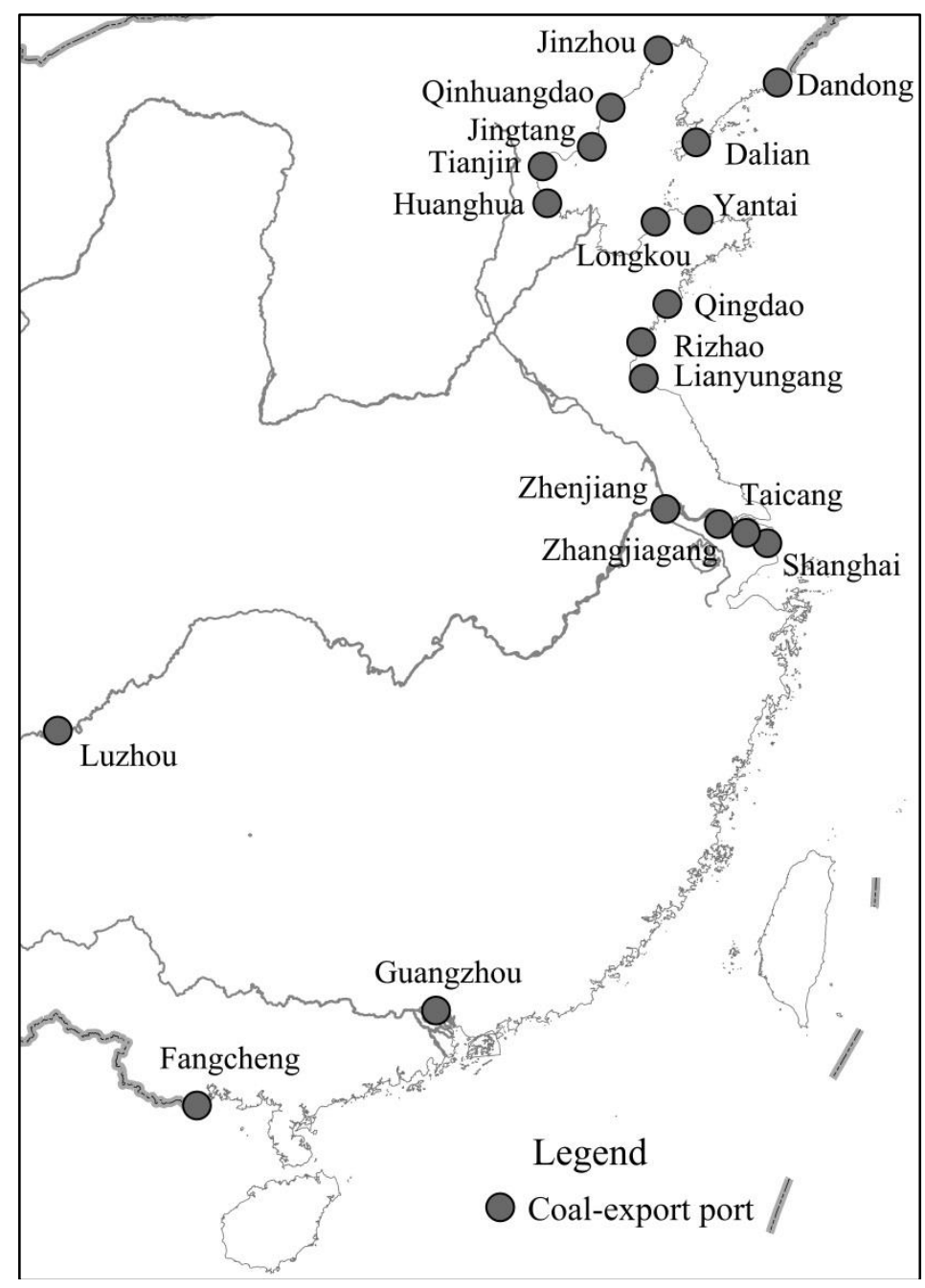

Figure 7: Major coal exporting ports in China 


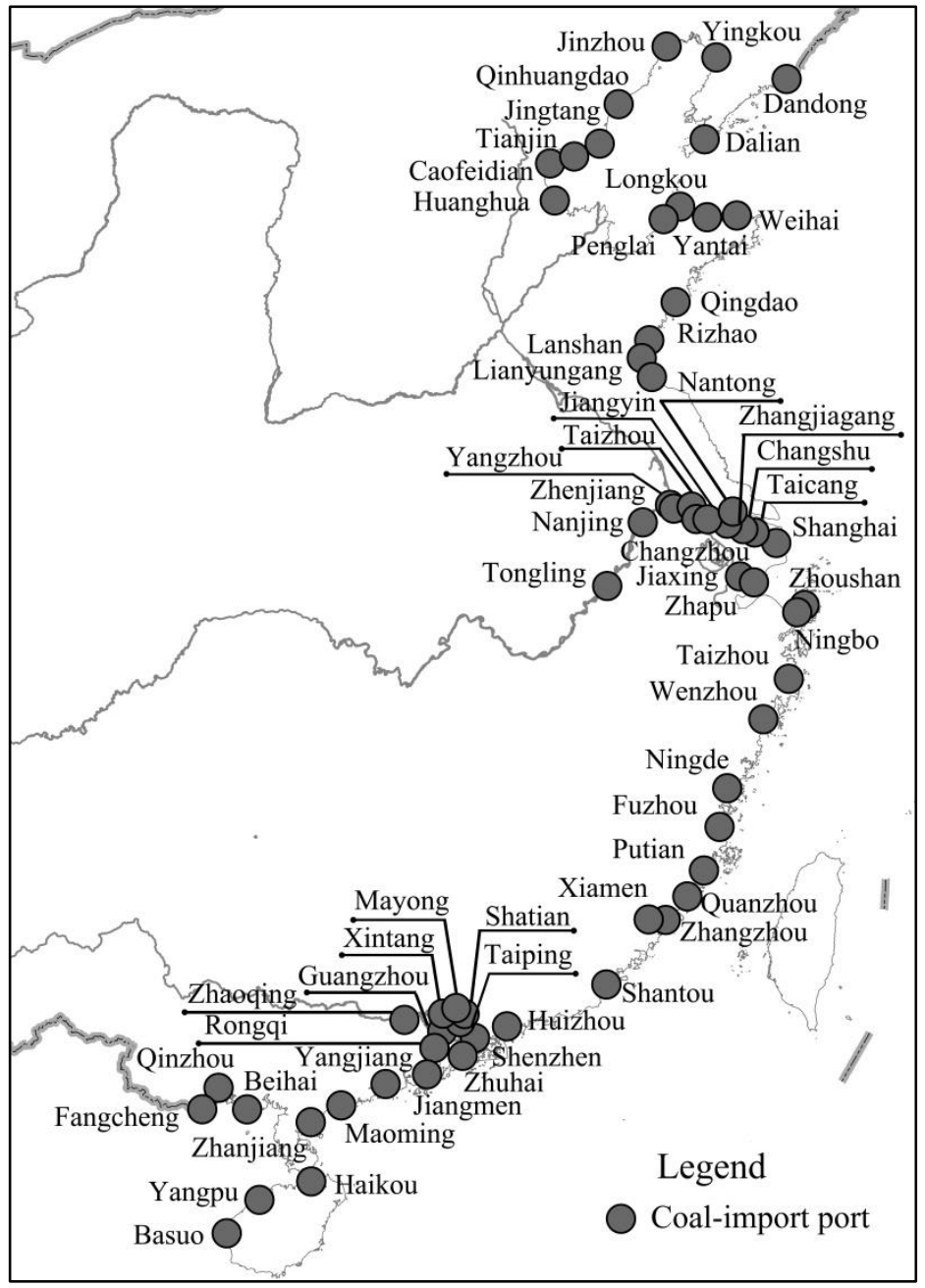

Figure 8: Major coal-importing ports in China 


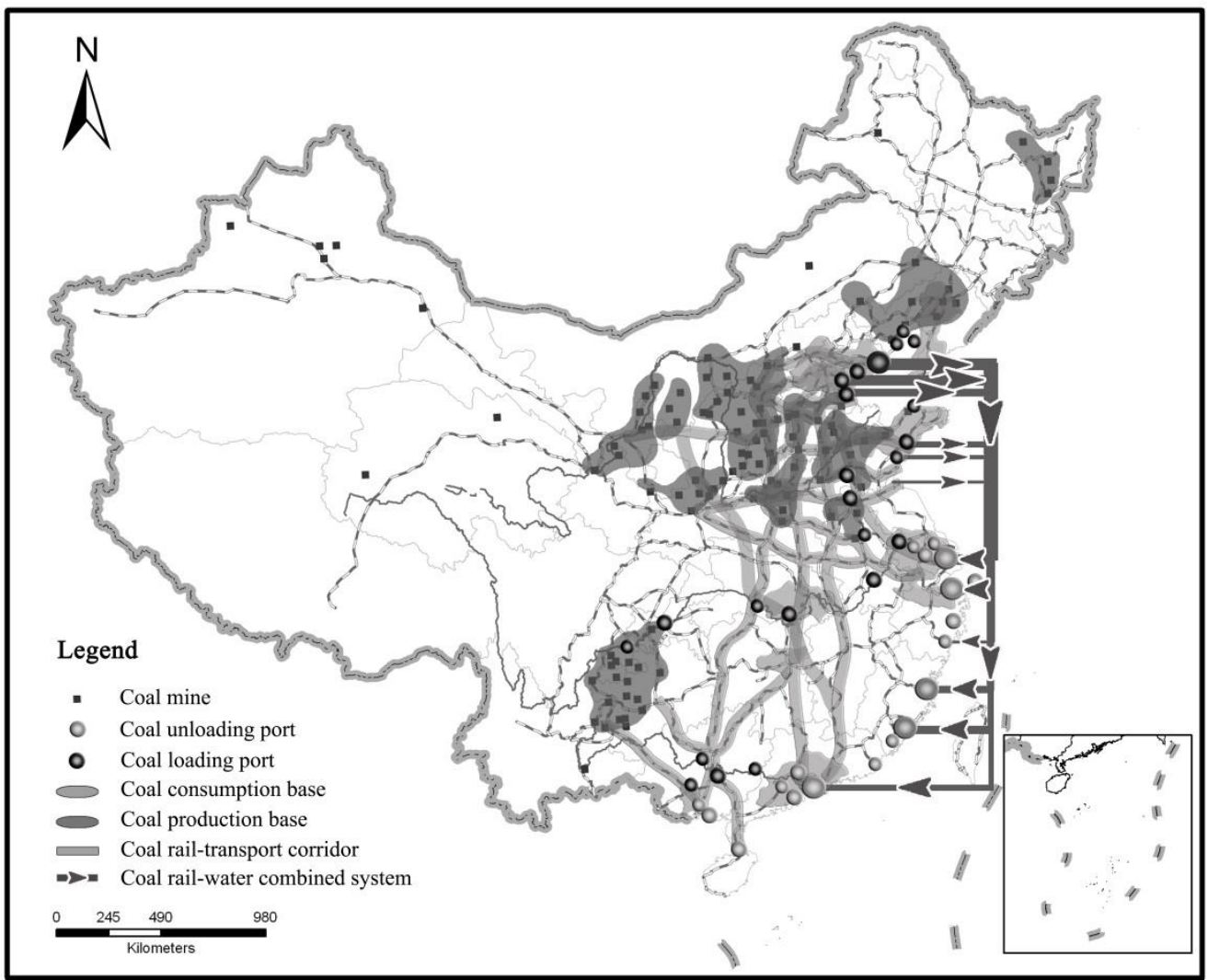

Figure 9: Spatial pattern of coal transfer by rail and rail-water combined systems

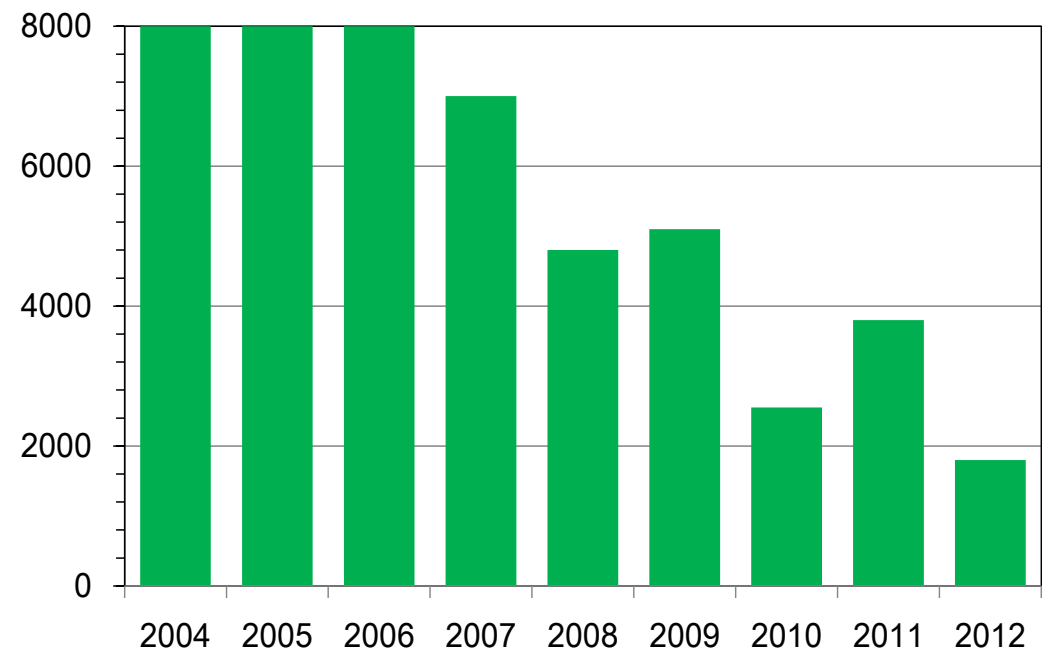

Figure 10: Developing trend of coal export quotas in China 


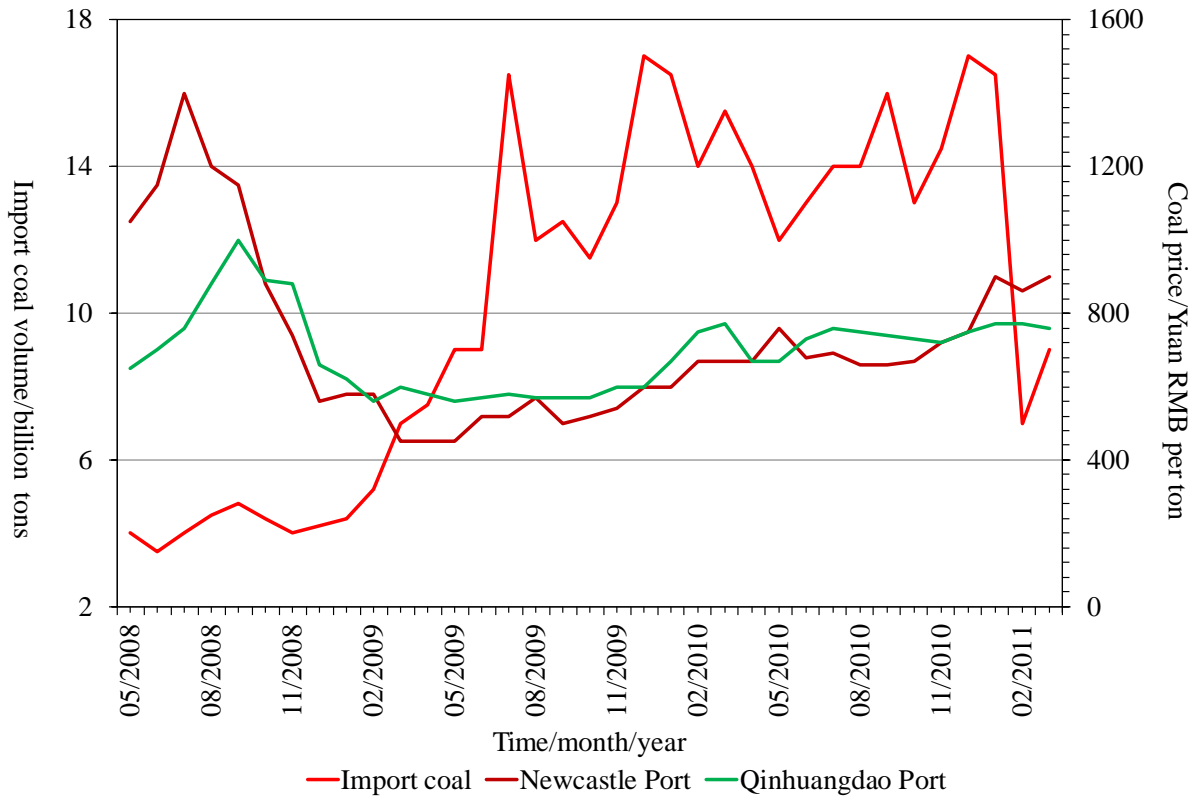

Figure 11: Import coal traffic and coal prices of Qinhuangdao (China) and Newcastle (Australia),

2008-2011 